\title{
Strain Behaviour in Composite Plate Girders with Imperfect Shear Connection
}

\author{
(Kelakuan Terikan Dalam Galang Plat Komposit Dengan Sambungan Ricih Tidak Sempurna)
}

M. Y. M. Yatim* \& N. E. Shanmugam

\begin{abstract}
This paper is concerned with the experimental study on the behaviour of strain in steel-concrete composite plate girders having imperfect shear connection. A number of slender girders of practical size were loaded to failure under shear applied at the mid-span. The main variables considered in this study are the longitudinal spacing of stud connector, diameter of stud shank, number of studs along the upper flange and concrete strength. Strains were measured extensively at specified load levels and locations across the concrete slab width and across the whole depth of the girder. The test results have shown variations of strain from girder to girder due to effects of reaction at supports, compression and tension parts of the girders as well as imperfection in the shear connection. Strains across the slab width show arbitrary respond with maximum tension and compression values of $4284 \mu \varepsilon$ and $4622 \mu \varepsilon$, respectively. Across the girder depth, girders with low degree of shear connection display high step change to the extent of $736 \mu \varepsilon$ due to incompatibility between two strains at the interface. Slip strain is found maximum near the mid-span of the girders in all cases.
\end{abstract}

Keywords: Composite plate girder; partial interaction; strain; behaviour

ABSTRAK

Kertas ini adalah mengenai kajian makmal terhadap kelakuan terikan dalam galang plat komposit konkrit-keluli dengan sambungan ricih tidak sempurna. Beberapa bilangan galang langsing dengan saiz yang praktikal dibebankan secara ricih pada tengah rentang sehingga gagal. Pembolehubah utama yang diambil kira dalam kajian ini ialah jarak mengufuk penyambung stud, garispusat batang stud, bilangan stud sepanjang bebibir atas dan kekuatan konkrit. Terikan-terikan diukur secara ekstensif pada aras beban tertentu dan lokasi merentasi lebar papak konkrit dan merentasi kedalaman menyeluruh galang. Keputusan uji kaji menunjukkan perubahan-perubahan terikan daripada galang ke galang disebabkan kesan tindak balas di penyokong, bahagian mampatan dan tegangan dalam galang serta ketidaksempurnaan dalam sambungan ricih. Terikan merentasi lebar papak menunjukkan respon yang tidak tentu dengan nilai tegangan dan mampatan masing-masing ialah $4284 \mu \varepsilon$ dan $4622 \mu \varepsilon$. Merentasi kedalaman galang, galang dengan darjah sambungan ricih yang rendah menunjukkan berlakunya perubahan langkah yang besar sehingga $736 \mu \varepsilon$ disebabkan oleh ketidakserasian antara dua terikan pada antaramuka. Terikan gelincir didapati maksimum berhampiran tengah rentang galang bagi kesemua kes.

Kata kunci: Galang plat komposit; interaksi separa; terikan; kelakuan

\section{INTRODUCTION}

Plate girder is of customised, built-up flexural member with flanges separated by deep and thin web for optimum design. Plate girders used in buildings or highway bridges are expected to support concrete deck slab. The constant need of cost-effective construction with satisfactory performance has led to utilisation of composite action. In a typical composite construction, steel plate girders and concrete slab are firmly connected together so that they may act compositely as a single unit, thus fully exploiting the advantages of the two different materials. In addition to individual strength of concrete slab and steel girder, the performance of a composite plate girder is dictated by stiffness of the shear connection between the two interacting elements. Theoretically, perfect composite interaction may be achieved when use of rigid shear connectors can completely fend off the relative horizontal movement and vertical separation of steel and concrete at the interface. Headed studs, the commonly used type of shear connector, are flexible in nature in the sense that they may deform to a certain extent depending on the connection properties and magnitude of shear force transmitted through the connectors. According to Oehlers et al. (1997), the shear connection is still categorised as partial though full interaction is adopted in the design. 
Partial interaction permits the occurrence of longitudinal slip that arises from strain discontinuity at the steelconcrete interface. Presence of slip gives rise to deflection due to additional curvature which in turn, lowers the flexural stiffness and strength of the composite members (Nie and Cai 2003). In many instances, it may be found that strength capacity of composite members is excessive when full interaction is assumed. It is often advantageous to provide fewer stud connectors than the calculated number required for full interaction. Fewer number of studs may be insufficient to develop full composite strength but yet adequate to just provide the strength required. The advantages of composite action can still be realised but in a somewhat reduced manner (Johnson and May 1975).

Massive amounts of past research have been directed towards the study on different aspects of composite beams and composite plate girders. Tests on composite beams with incomplete interaction were carried out by Newmark et al. (1951). In accordance with small deformation elastic analysis and employing Euler-Bernoulli's beam theory, a second order differential equation for slip allowed composite beam was derived by assuming equal curvature between the interacting elements. Daniels and Fisher (1967) reported experimental tests on two simple span composite beams to investigate the load-deflection, load-slip and load-rotation relationships. Adekola (1968) presented an interaction theory for composite beams allowing for interface friction, slip and negative uplift deformation. Fourth and second order coupled differential equations connecting the uplift tension and axial force within the elements were derived and solved by finite difference method. Theoretical formulations for short-term and time dependent response of composite beams under sustained loads accounting for the effect of interface slip were proposed by Bradford and Gilbert (1992), leading to an iterative solution for curvatures, strains and deflections.

Two-dimensional finite element formulation for simply supported and continuous composite beams with flexible shear connection was developed by Oven et al. (1997). The analysis has shown that maximum interface slip occurs at both ends, indicating that stud connectors located near end supports are stressed beyond the elastic limit. In continuous beams, however, the slip behaviour at the interior support regions is uncertain that no clear pattern of slip progression can be identified due to complex nature of slip distribution. Jasim (1999) applied partial interaction theory to develop equations for deflection of composite beams with varying density of shear connector along the span. A general design chart for deflection at the midspan was proposed. Seracino et al. (2001) introduced the concept of focal point to derive partial interaction flexural stresses from full interaction analysis. The concept was also applied to continuous composite beams (Seracino et al. 2004, 2006). Queiroz et al. (2007) presented modelling technique to analyse composite beams accounting for full and partial shear connection using a finite element system.
Use of discrete non-linear spring element for modelling the studs was found to be efficient as far as computational time and accuracy of results are concerned.

Porter and Cherif (1987) presented experimental investigation on small-scale models of composite plate girders. Theoretical solution was outlined to predict the ultimate strength based on the failure mechanism. Shanmugam and Baskar (2008) studied the ultimate load behaviour of composite plate girders under shear and negative bending moment. All the test specimens were designed for full composite interaction. Principal strain in webs was measured to study the extent of tension field due to effect of composite action. Shanmugam et al. (2009) utilised finite element method to analyse composite plate girders by assuming perfect composite interaction between concrete slab and steel girder. Based on design procedures proposed earlier by Shanmugam and Baskar (2006), an approximate method to predict the shear strength of the girders was proposed. On the basis of past works (Narayanan and Der Avanessian 1983; Darehshouri et al. 2011; Darehshouri et al. 2012), Yatim et al. (2012) and Darehshouri et al. (2013) proposed analytical methods for ultimate strength of composite plate girders under shear, accounting for the properties of shear connection. Accuracy of the approximations was established through comparisons with the corresponding experimental results and finite element predictions. Sherafati et al. (2013) reported an experiment on composite plate girder under shear and positive bending to examine the mechanics of failure, flexural behaviour, out-of-plane deformation of web surface and principal strains at the centre of the web.

Studies on composite plate girders are many. However, those dealing with partial interaction are rare, except that the work by Allison et al. (1982) who carried out tests on large-scale composite plate girders under the action of combined shear and negative bending to examine the interaction between web tension field and shear connection. Most related studies solely involved numerical formulations or computer modelling which do not provide a broad perspective with respect to the behaviour of such girders. Therefore, there is a necessity to get a clear picture of their behaviour through physical observations in order to enhance the understanding of the characteristics of composite plate girders with imperfect shear connection.

In this paper, experimental investigations on composite plate girders with partial interaction are described. Girders of real size used in practice were tested to failure under monotonic loading applied at the centre of the span. In order to induce 'imperfection' in the composite action, different properties of shear connection were considered by variation in concrete strength including spacing, size and number of stud connectors along the flange. In the present study, attention is focused on variations of strain in the girders and overall behaviour at ultimate conditions due to effects of partial interaction. Details of the experiments are reported herein along with the results obtained. 


\section{EXPERIMENTAL PROGRAMME}

DETAILS OF THE TEST SPECIMENS

Test specimens in the present study were designed based on those tested by Shanmugam and Baskar (2003). The configuration was modified to suit the conditions of test facilities as well as the intentions of the study. Eight identical girders having different longitudinal spacing, dimensions and number of stud connectors were analysed as composite sections using finite element method to ascertain whether they are susceptible to lateral torsional buckling or overturning especially at high load levels. In addition, the finite element analysis is necessary to predict the preliminary results so that the rate of loading can be estimated accordingly during the test as well as to confirm that the loading capacity of the available actuator is adequate.

The steel plate girders were fabricated from mild steel plates of Grade S275. Flat steel plates of different thicknesses were measured, marked and machined accurately to size. All of the components were welded together with continuous fillet welds using low temperature system to minimise the welding distortion. Stiffeners were welded accordingly on both sides of the web plate. The basic dimensions were kept the same in all the girders in order to have constant span length of $3655 \mathrm{~mm}$, web thickness of $3 \mathrm{~mm}$, flange width of $200 \mathrm{~mm}$, flange thickness of 20 $\mathrm{mm}$, web slenderness ratio of 250 and web aspect ratio of 1.16. Three different headed studs of $16 \mathrm{~mm}, 19 \mathrm{~mm}$ and 25 mm shank diameters with ultimate tensile strength, $f_{u}$ not greater than $500 \mathrm{MPa}$ were welded at different longitudinal spacing on the top flange of the girders to obtain specified degrees of interaction when acting compositely with the concrete slab.

The girders are named as G1C20, G1C30, G2C30, G3C30, G4C20, G4C30, G5C30 and G6C30. Notations $\mathrm{C} 20$ and $\mathrm{C} 30$ refer to concrete grade whilst notations G1 to G6 indicate different diameter or spacing of stud connectors along the span. Details of the shear connection are summarised in Table 1 . In the table, $B_{c}$ and $H_{c}$ denote width and thickness of the concrete slab, respectively. Figures 1(a) to 1(c) show the elevation and cross-sections of a typical test girder.

TABLE 1. Shear connection properties of the test girders

\begin{tabular}{|c|c|c|c|c|}
\hline Girder & $\begin{array}{l}\text { Diameter and spacing of studs } \\
\qquad(\mathrm{mm})\end{array}$ & $\begin{array}{l}\text { Degree of } \\
\text { interaction } \\
\quad(\%)\end{array}$ & $\begin{array}{l}\text { Dimensions of } \\
\text { concrete slab } \\
B_{c} \times H_{c}(\mathrm{~mm})\end{array}$ & $\begin{array}{l}\text { Diameter and spacing of } \\
\text { reinforcement } \\
(\mathrm{mm})\end{array}$ \\
\hline G1C20 & 19 at 135 centres in pairs & 100 & \multirow{8}{*}{$\begin{array}{l}1000 \times 150 \\
\text { (applied to all } \\
\text { concrete slabs) }\end{array}$} & \multirow{8}{*}{$\begin{array}{l}10 \text { at } 150 \text { centres } \\
\text { in transverse and } \\
\text { longitudinal directions, } \\
\text { top and bottom layers } \\
\text { (applied to all } \\
\text { concrete slabs) }\end{array}$} \\
\hline G1C30 & 19 at 135 centres in pairs & 100 & & \\
\hline $\mathrm{G} 2 \mathrm{C} 30$ & 19 at 279 centres in pairs & 50 & & \\
\hline G3C30 & 19 at 465 centres in pairs & 30 & & \\
\hline G4C20 & 19 at 465 centres in single row & 15 & & \\
\hline G4C30 & 19 at 465 centres in single row & 15 & & \\
\hline G5C30 & 16 at 116 centres in pairs & 80 & & \\
\hline G6C30 & 25 at 465 centres in pairs & 50 & & \\
\hline
\end{tabular}

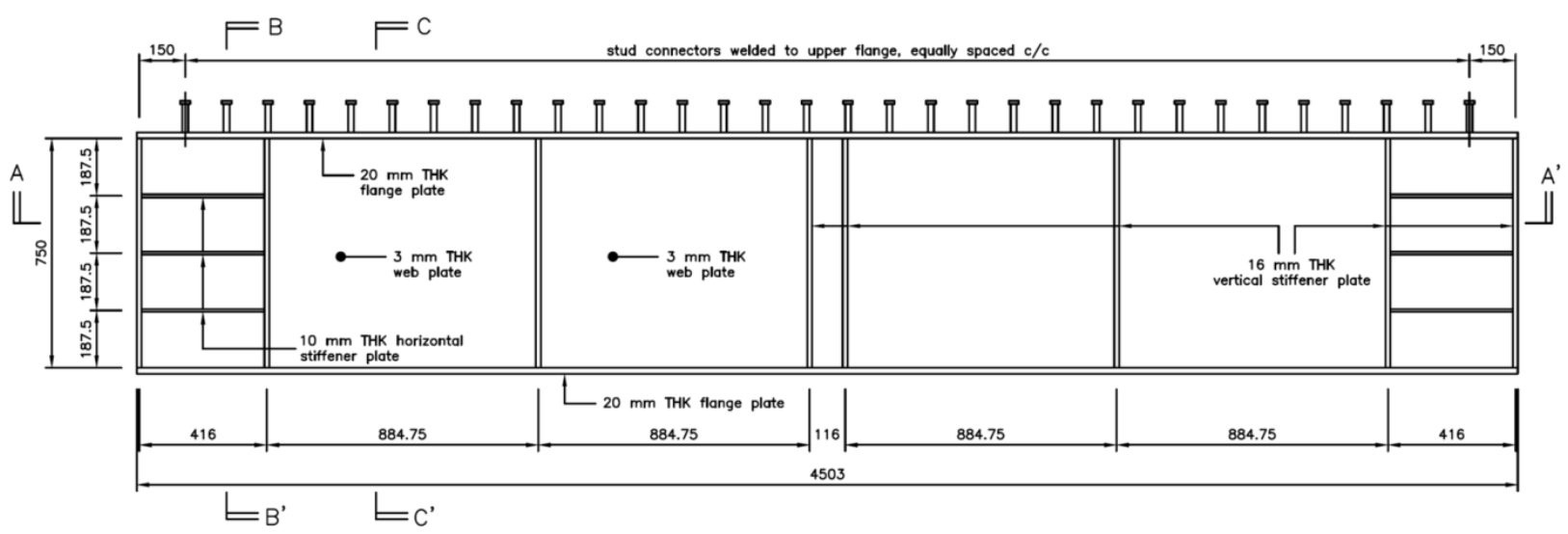

(a) 


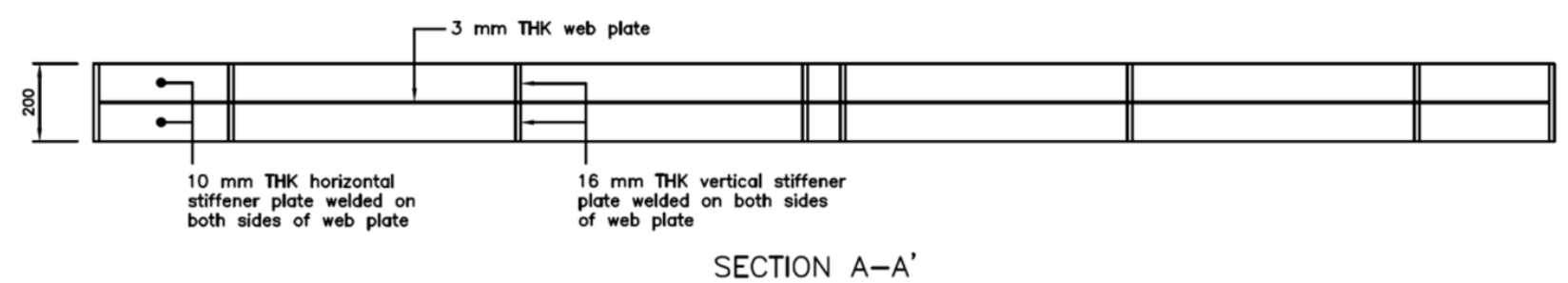

(b)

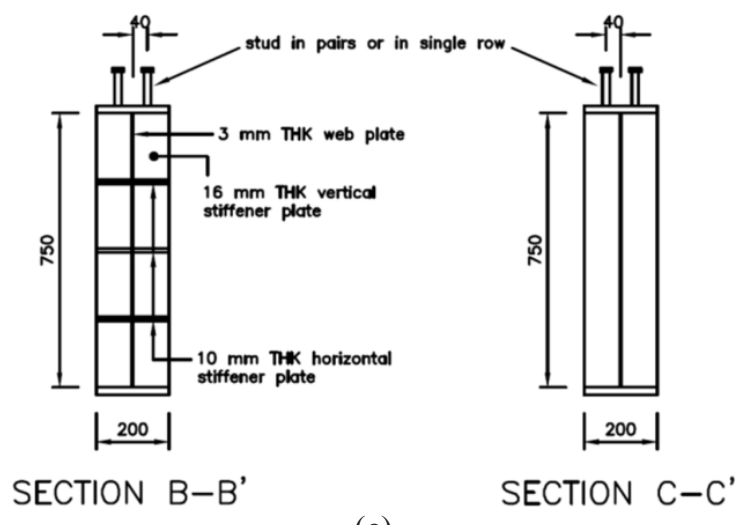

(c)

FIGURE 1. Typical details of steel plate girder

(a) Typical test girder

(b) Sectio A-A'

(c) Section B-B; \& C-C'

CASTING OF CONCRETE SLAB

Steel plate girders were placed on a level floor in the laboratory and formworks with specified dimensions for the upper concrete slabs were constructed using plywood. Construction joints in the formworks were sealed with silicon sealant for preventing any leakage of cement slurry during casting. The formworks were brushed up with oil so that they could be easily removed after the concrete hardened. Two mesh layers of reinforcing bars of $10 \mathrm{~mm}$ diameter, spaced at $150 \mathrm{~mm}$ centres in both directions, were placed in the formwork along the entire length of the concrete slab. Concrete cover of $20 \mathrm{~mm}$ was provided for the protection of top and bottom reinforcements.

The concrete mixture consists of crushed natural aggregates with maximum size of $20 \mathrm{~mm}$ and $60 \%$ of fine aggregate passed through the 600 micron test sieve. Slump of $50 \mathrm{~mm}$ was specified to give medium workability mixes. Two characteristic strengths of concrete, namely 20 and $30 \mathrm{MPa}$ were employed in this study. Based on the established design practice and practical considerations (Wang and Chung 2008), the width of concrete slab, $B_{c}$ is taken as $1000 \mathrm{~mm}$ with an overall depth, $H_{c}$ of $150 \mathrm{~mm}$. Sufficient care was taken during concreting to ensure that the mixture is properly compacted using a power-generated needle vibrator as shown in Figure 2 in order to prevent honeycombs especially near the stud regions. However, vibrating the concrete too long may cause segregation of aggregates and therefore, was avoided during the consolidation process. The day after casting, the formworks were removed and the hardened concrete slabs were cured and air-dried in the laboratory until the day of testing.

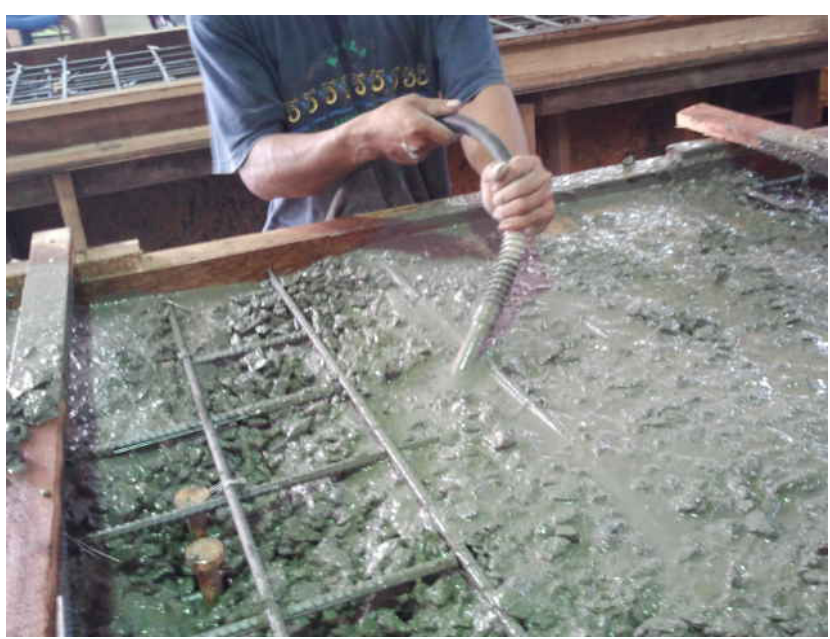

FIGURE 2. Compaction of concrete

\section{INSTRUMENTATION AND TEST SET-UP}

Extensive instrumentation was provided in terms of strain gauges and transducers as shown in Figures 3(a) to 3(e). In the figures, ST and TR denote strain gauge and transducer, respectively. Electrical resistance TML type linear strain gauges were placed at 27 selected points on the surfaces of concrete slab and steel girder as illustrated in Figures 3(a), 3(b) and 3(c) in order to obtain details of strain variations in the girder. Prior to mounting the strain gauges, the concrete slab was white-washed using a special paint made from slaked lime and chalk so that cracks and failure patterns in concrete can be clearly identified during the testing. The concrete surface at the strain gauge positions was then 
cleaned using the abrasive papers. The flange and web plates were cleaned at locations corresponding to strain gauges using acetone so that the surface is free from any oil or grease. After the gauge positions were marked precisely, the strain gauges were mounted carefully by means of an appropriate fast-setting adhesive. The strain gauges were then covered with plastic for protection. Lead wires were soldered to the terminals of the strain gauges. Soldering was assumed to be satisfactory if the readings were found stable when connected to a multimeter.

Displacements were measured using general purpose Kyowa type LVDT transducers at locations shown in Figures 3(d) and 3(e). These measurements enabled plotting of deflection profiles, interface slips along the length of the girders and the end slips at different loading stages. All strain gauges and transducers were connected to Kyowa type data logger which could display visually the results through a computer at the time of testing. The tests were carried out in a self-straining test rig in the laboratory. Monotonic loading was applied through a computerised $1000 \mathrm{kN}$ capacity Instron servo-hydraulic actuator with a maximum stroke of $\pm 250 \mathrm{~mm}$. The test girder was placed over the strong supports at their end bearing stiffeners to avoid local failure of flange and web. Sufficient care was taken to ensure that the girders are positioned correctly in the test rig in such a way that the mid-span of the girders are in line with the centre line of the actuator's load cell. View of a typical test set-up is shown in Figure 4. Nevertheless, only results for strains at specified load levels are presented in this paper whilst other results and properties of steel and concrete materials including details of the test procedure may be found in the reference (Yatim et al. 2015).

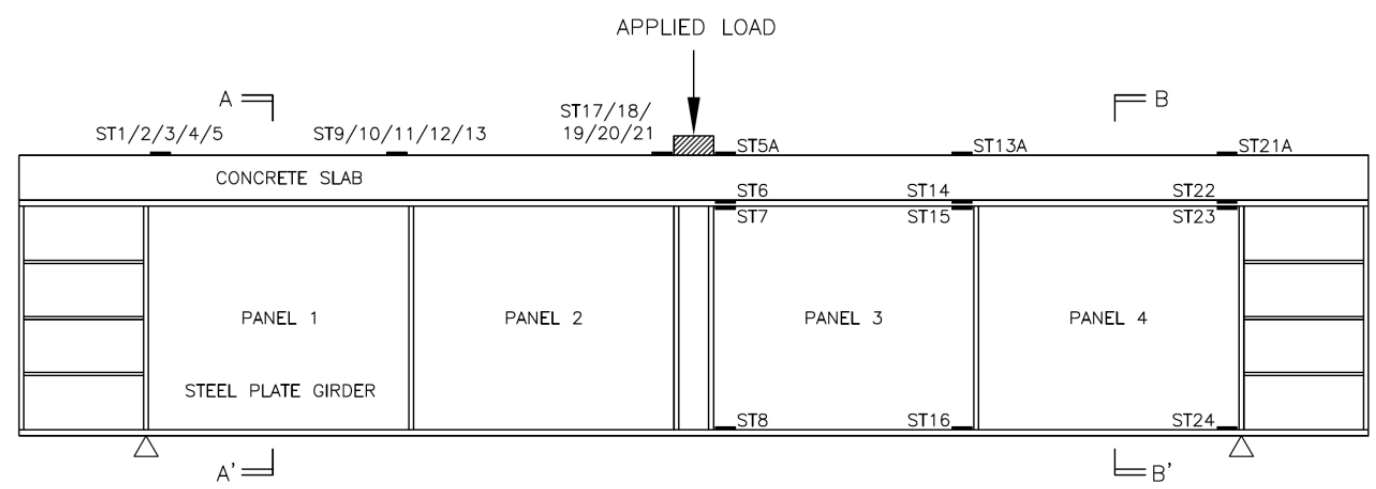

(a)

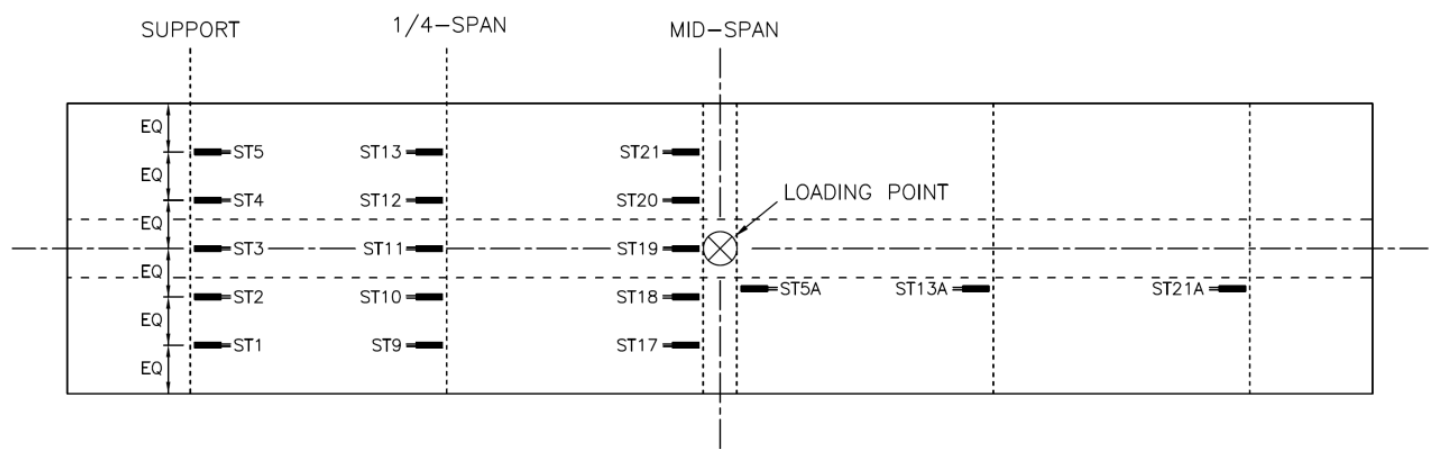

(b)
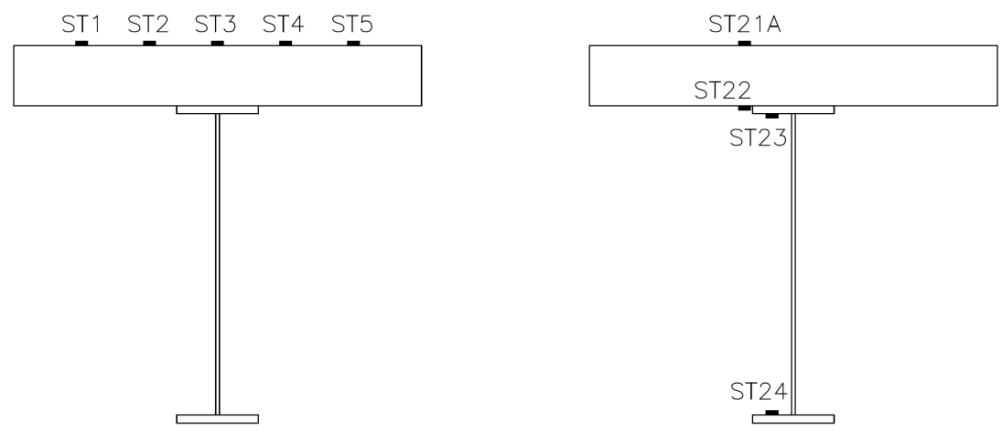


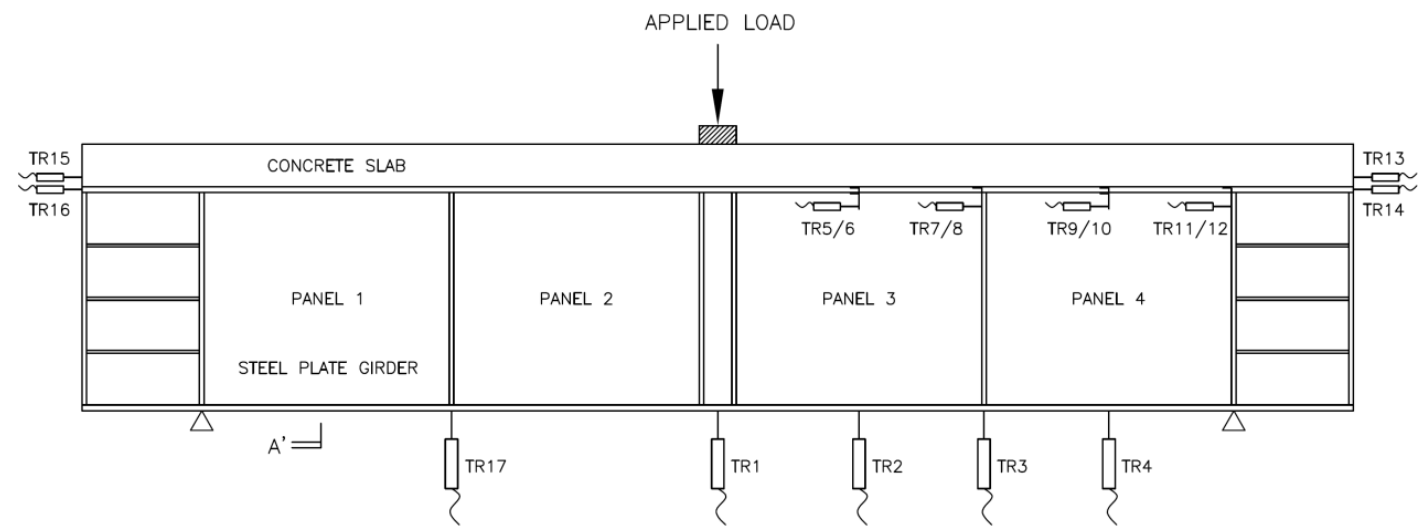

(d)

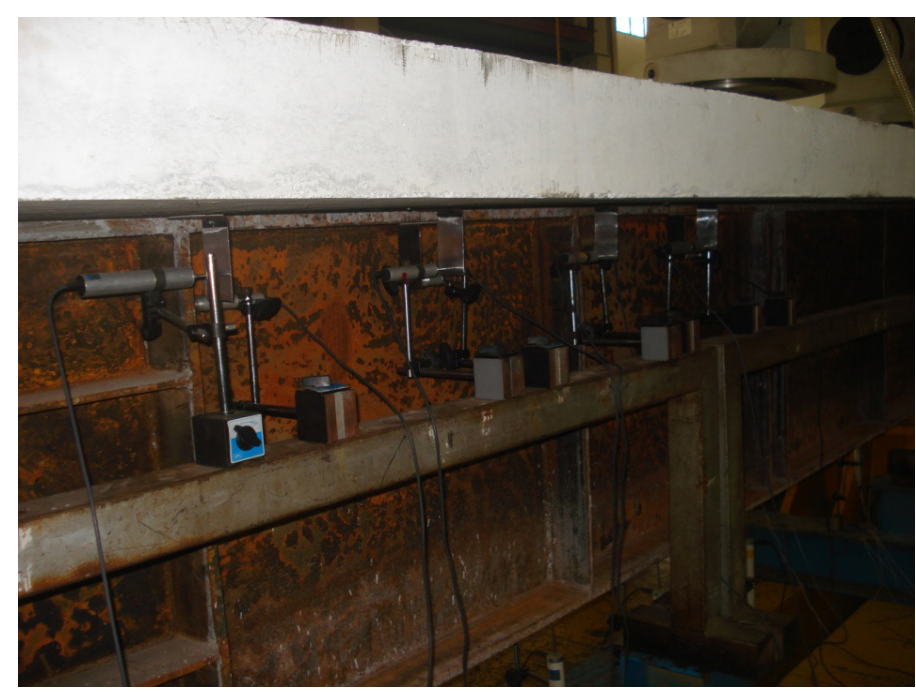

(e)

FIGURE 3. Details of strain gauge and transducer locations

(a) Details of strain gauge locations in the girder

(b) Plan view of concrete slab showing the strain gauge locations

(c) Sectional views at $A-A$ ' and $B-B$ ' showing the strain gauge locations

(d) Details of transducer locations

(e) Locations of transducer for slip measurement

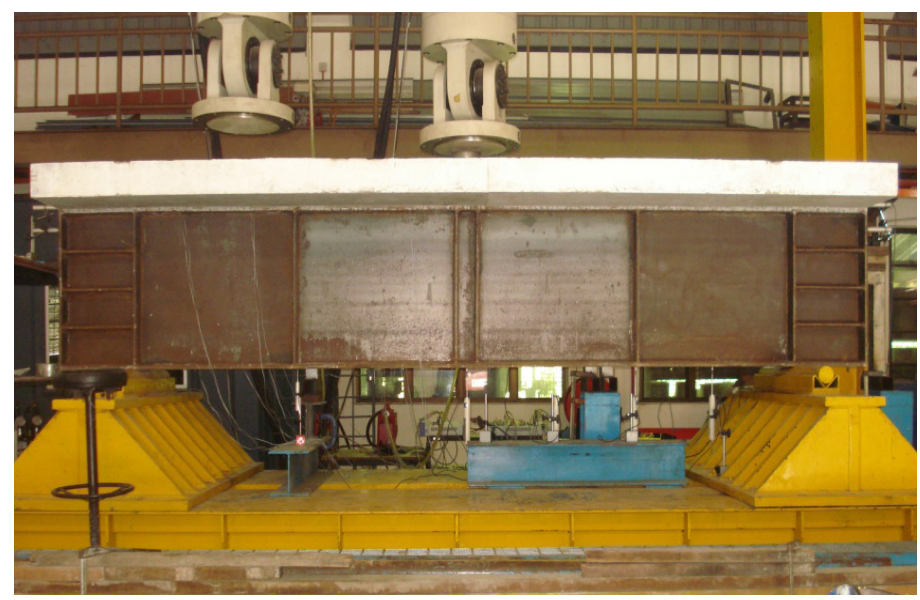

FIGURE 4. Typical view of the test set-up 


\section{RESULTS AND DISCUSSION}

INTERPRETATION OF THE MEASURED STRAINS ACROSS THE SLAB WIDTH

Longitudinal strain measurements were made across the slab width at three selected locations along the span as depicted in Figures 3(a) and 3(b). The first location refers to the section near the support, the second at the one-quarter span and the third near the mid-span. Measurements were made at five different points viz., ST1 to ST5 near the support location, ST9 to ST13 at one-quarter span and ST17 to ST21 near the mid-span, respectively. Strains were recorded for each load increment. However, the measured strains are plotted for load levels corresponding to $100 \mathrm{kN}$, $200 \mathrm{kN}, 300 \mathrm{kN}, 400 \mathrm{kN}, 500 \mathrm{kN}$ and $600 \mathrm{kN}$ as shown in Figures 5 to 7 .

Figures 5(a) to $5(\mathrm{~h})$ show the strains across the slab width near the support location. It can be seen from the figures that variation in strain is uncertain, indicating that the behaviour differs from one girder to another. In all girders, the pattern shows similarity from one load

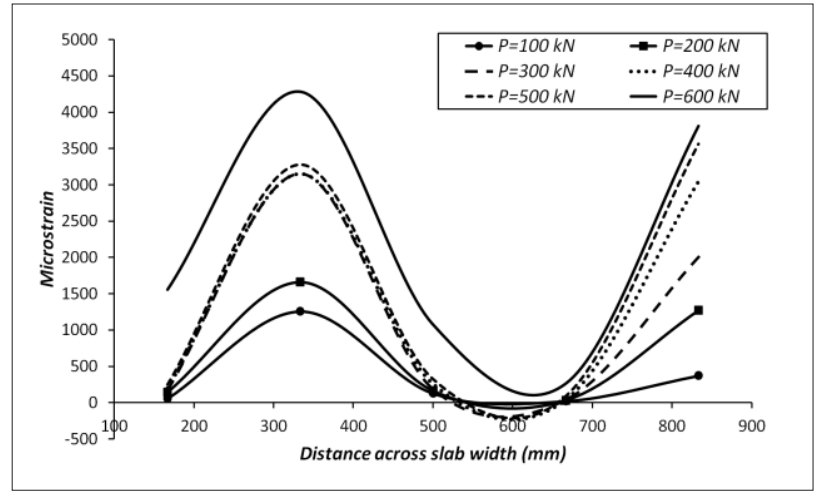

(a)

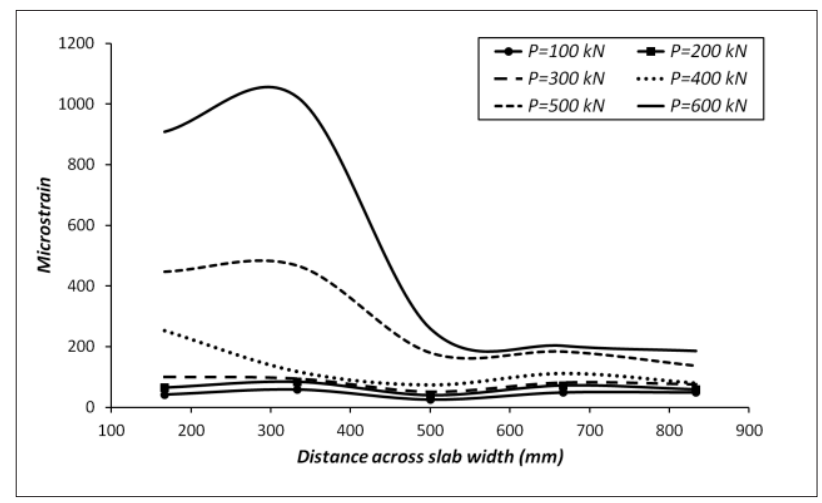

(c) level to another. Also, strains in all girders are of positive magnitude which indicates tension in the top fibre of concrete at support resulting from the upward reaction force. The strain readings rise with the increase in applied load. The maximum recorded strain is 4284 microstrain $(\mu \varepsilon)$ measured by strain gauge ST2 in the girder G1C20 at $600 \mathrm{kN}$. Such high magnitude of strain clearly indicates the formation of large crack width at the concrete surface. Effects of concrete strength and spacing of studs on the strain behaviour could not be justified clearly since it is greatly governed by the propagation of crack which is arbitrary across the slab width.

Also, it can be noticed that strain variation at the early stages of loading is fairly uniform across the slab width in most of the girders. However, the strain distribution becomes non-uniform across the width at higher load levels, indicating gradual formation of cracks in the slab. The acceptable distribution of strain should be with larger strain at the middle of the slab above the web and lower towards the edges as indicated in Figure 5(h) for the girder G6C30.

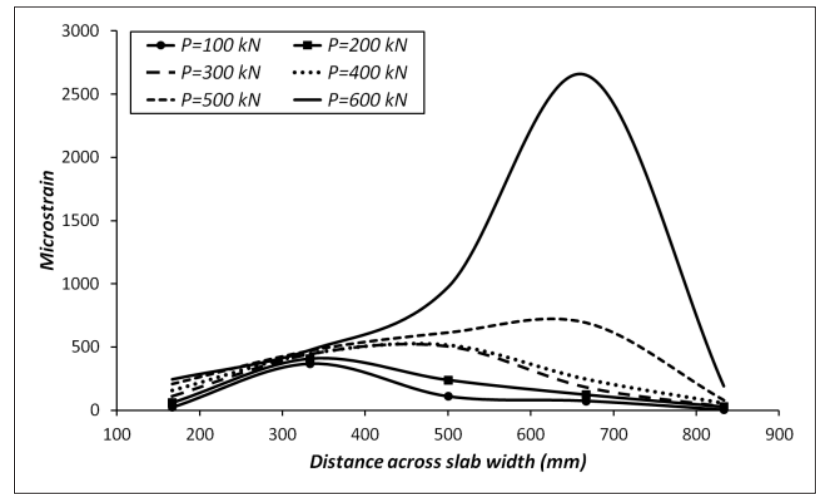

(b)

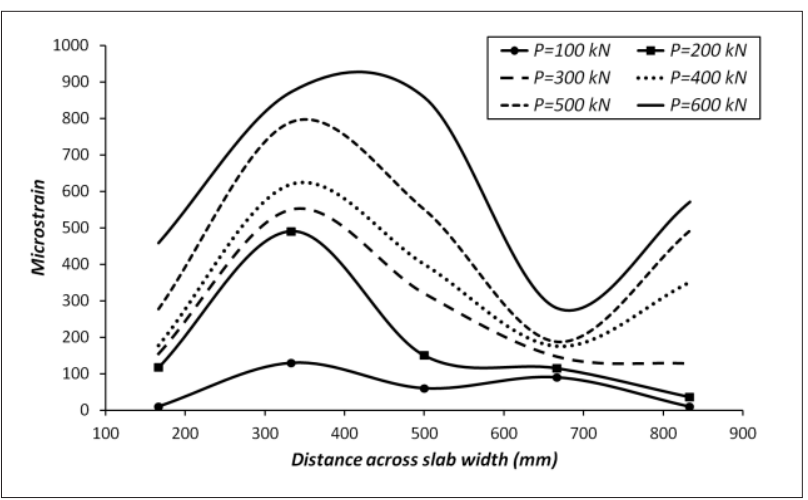

(d) 


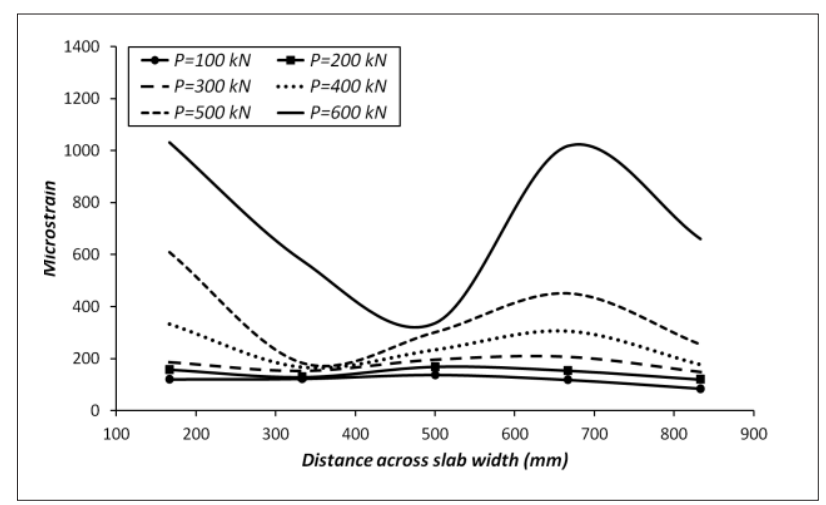

(e)

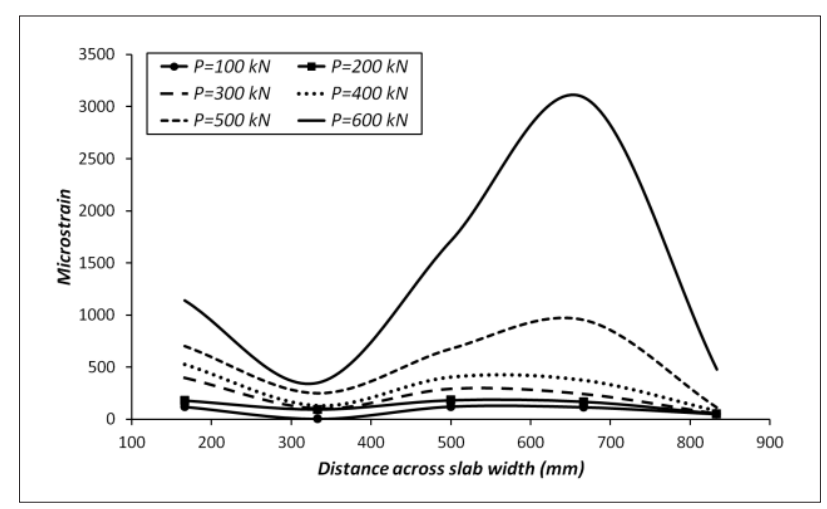

(g)

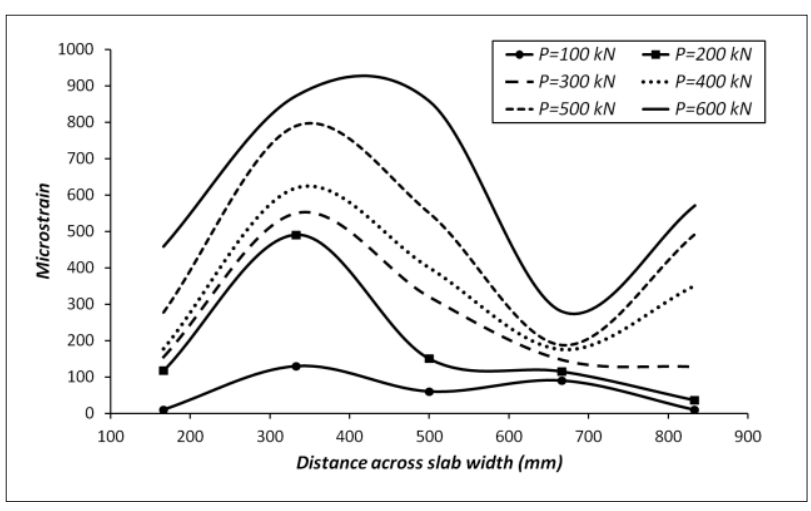

(f)

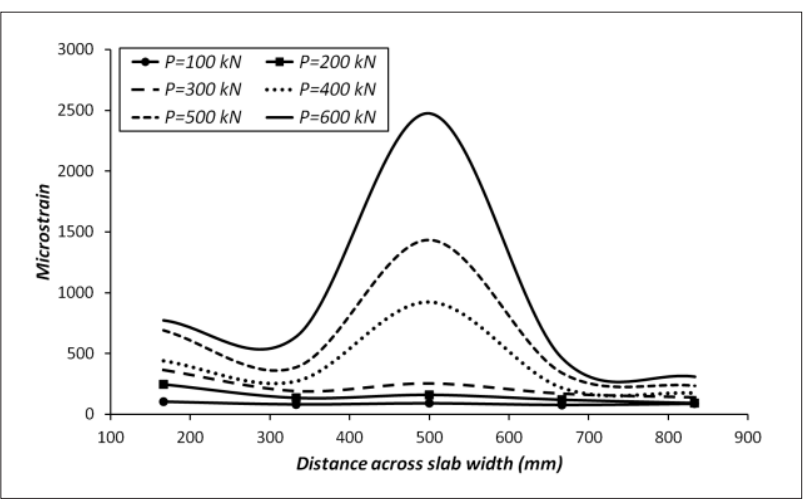

(h)

FIGURE 5. Strains across slab width near the support

(a) Girder G1C20 (b) Girder G1C30 (c) Girder G2C30 (d) Girder G3C30

(e) Girder G4C20 (f) Girder G4C30 (g) Girder G5C30 (h) Girder G6C30

Figures 6(a) to $6(\mathrm{~h})$ present the measured strains across the slab width at one-quarter span. At this section, variations of tensile and compressive strains can be seen and the behaviour varies from girder to girder. In the girder G4C30 and G6C30, for example, strains recorded at the middle width of concrete slab (strain gauge ST11) show positive values but near the edges (strain gauges ST9 and ST13), the values are of negative magnitude. These indicate an arbitrary response at the top fibre of concrete slab. It should be noted that strains at the mid-width (strain gauge

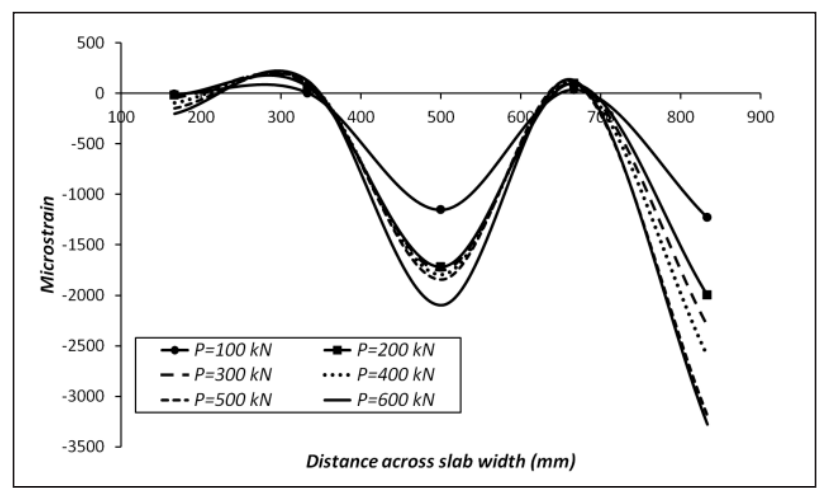

(a)
ST11) are in compression when shear studs were located near the considered section as exhibited by girders G1C20, G1C30, G2C30 and G5C30. Nevertheless, studs in girders G3C30, G4C20, G4C30 and G6C30 are considerably far away from the section where strains were measured, thus giving tensile strains at the particular point. This may be attributed to the fact that when studs are far from the measured point, the concrete is able to stretch to a certain extent and thus, induces tension in the fibre especially in the girders with low degree of interaction.

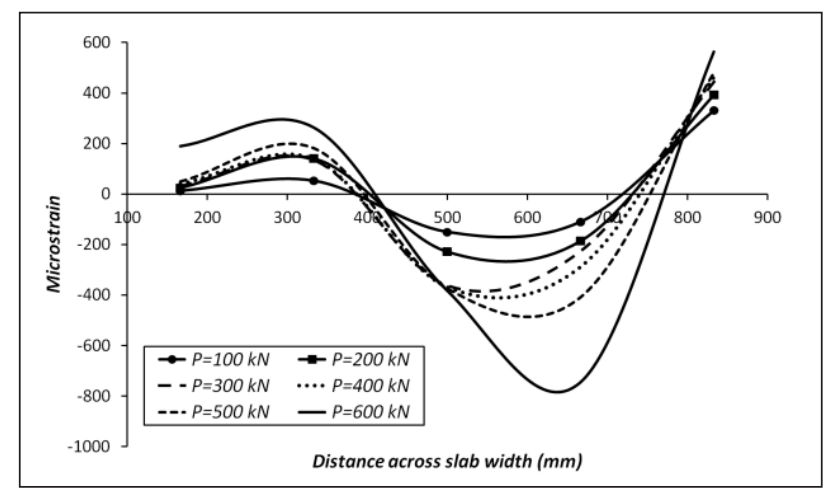

(b) 


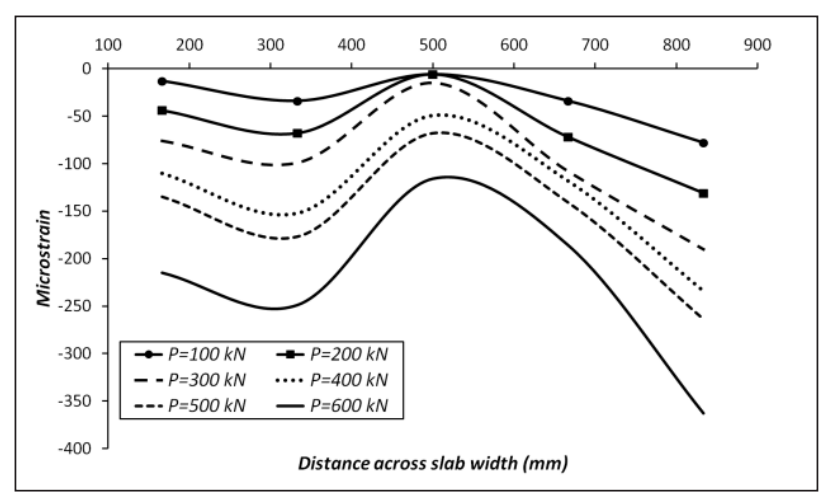

(c)

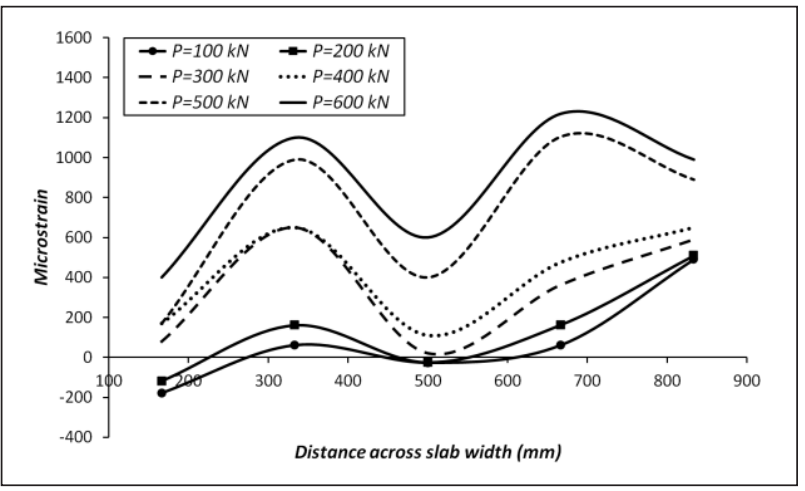

(e)

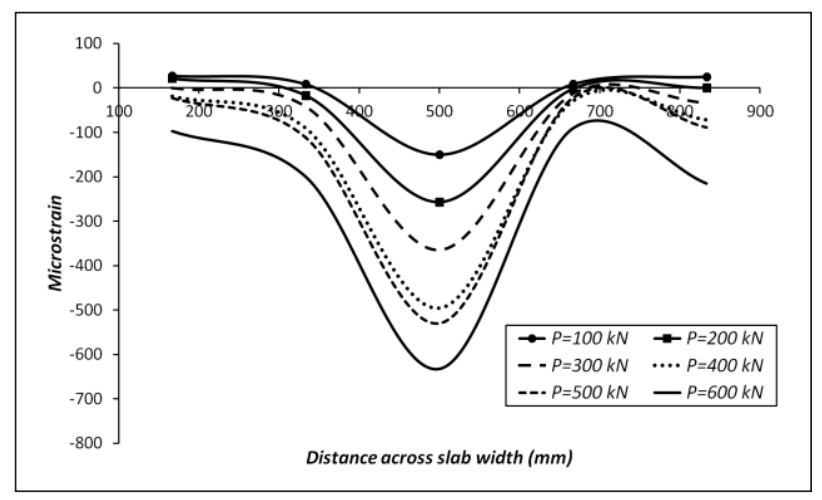

(g)

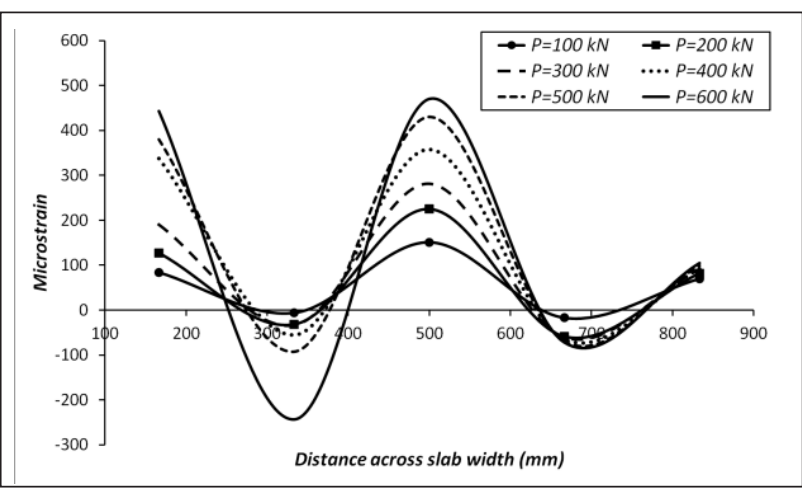

(d)

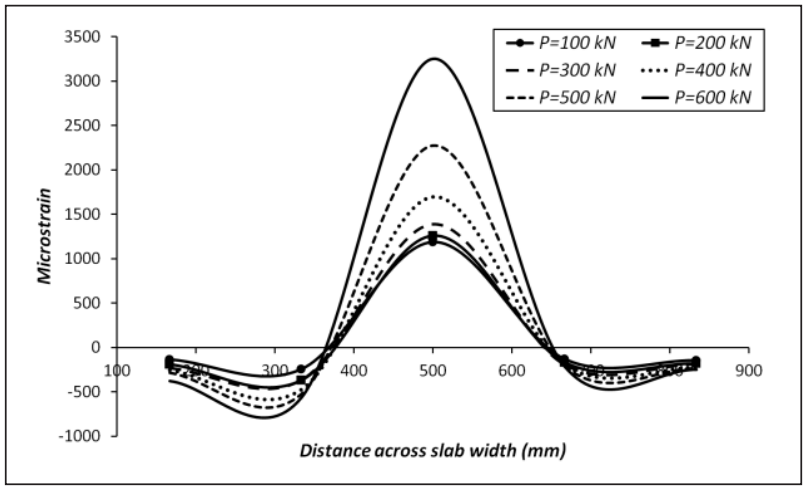

(f)

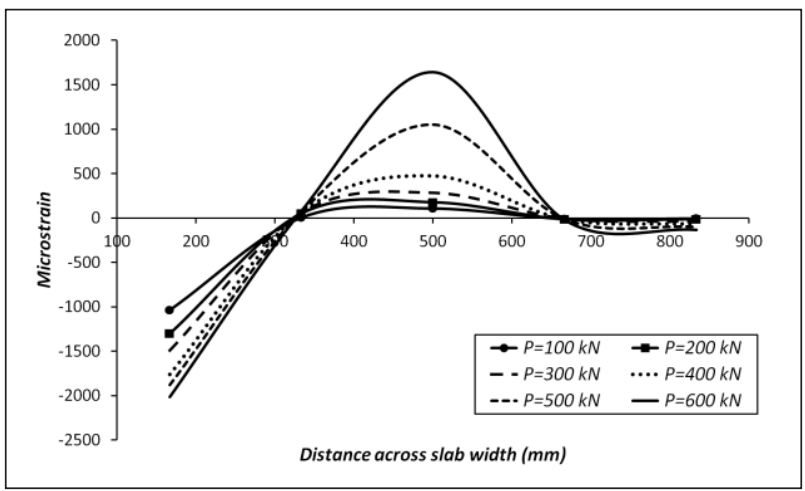

(h)

FIGURE 6. Strains across slab width at one-quarter span

(a) Girder G1C20 (b) Girder G1C30 (c) Girder G2C30 (d) Girder G3C30

(e) Girder G4C20 (f) Girder G4C30 (g) Girder G5C30 (h) Girder G6C30

Figures 7(a) to 7(h) show the recorded strains across the slab width near the point of load application at the mid-span. It can be seen from the figures that strains at all points are in compression as indicated by negative magnitudes. The strain distribution is uncertain throughout the width of the concrete slab and the behaviour varies from girder to girder. In each of the girders, the strain plots exhibit similar pattern for all the load levels considered. At a load level of $600 \mathrm{kN}$, high compressive strains were recorded, indicating crushing at some portions of the concrete surface. The maximum compressive strain is measured as $4622 \mu \varepsilon$ at the middle width of the concrete slab in the girder G3C30 (Figure 7(d)). Theoretically, this is an acceptable distribution of strain in which larger strain occurred at the middle of the slab above the web and lower towards the edges. Based on the results presented herein, influence of partial interaction on the strain variation across the slab width could not be clearly identified due to many uncertainties. Change in material properties across the section, stress distribution due to the applied load, uneven point of local failure and experimental errors are among the factors that lead to such behaviour of strain. 


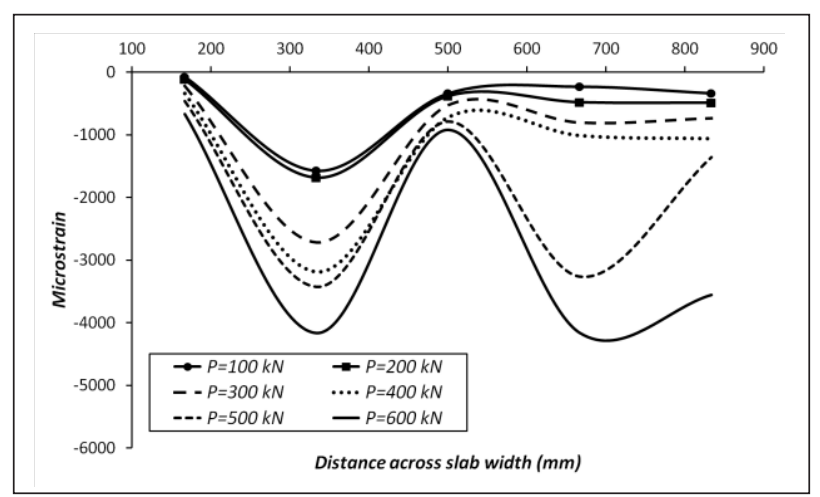

(a)

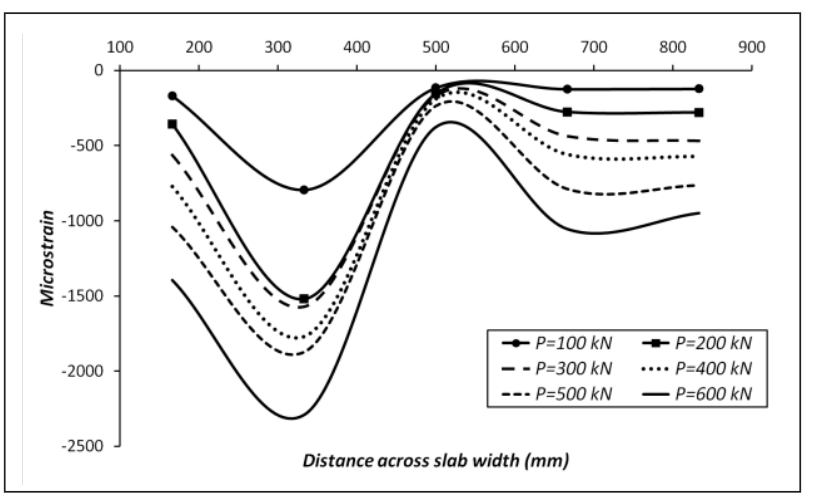

(c)

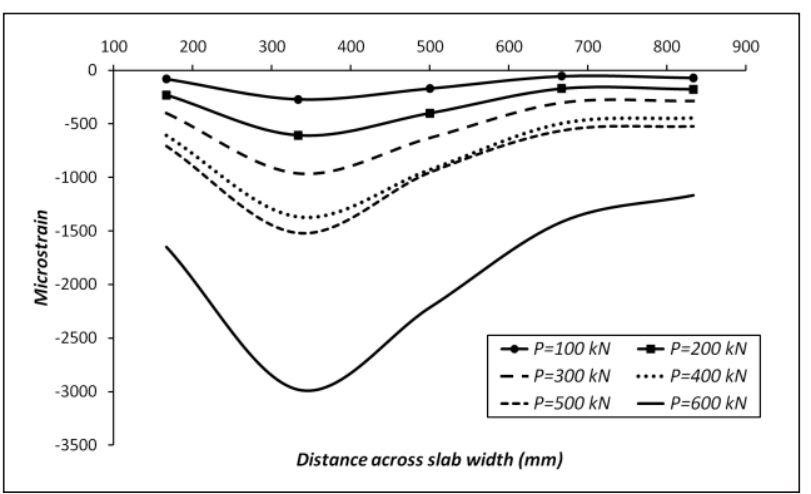

(e)

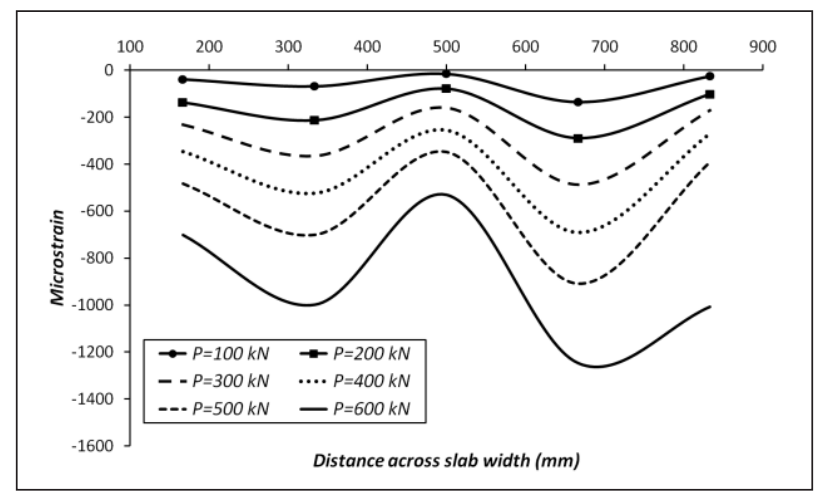

(g)

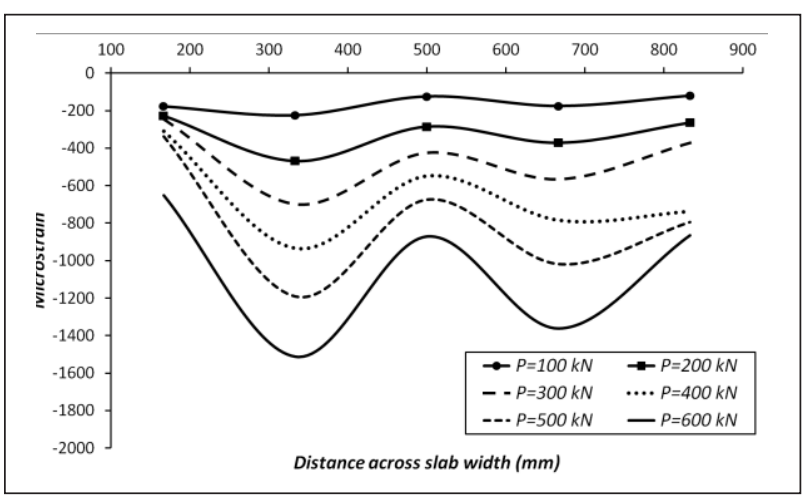

(b)

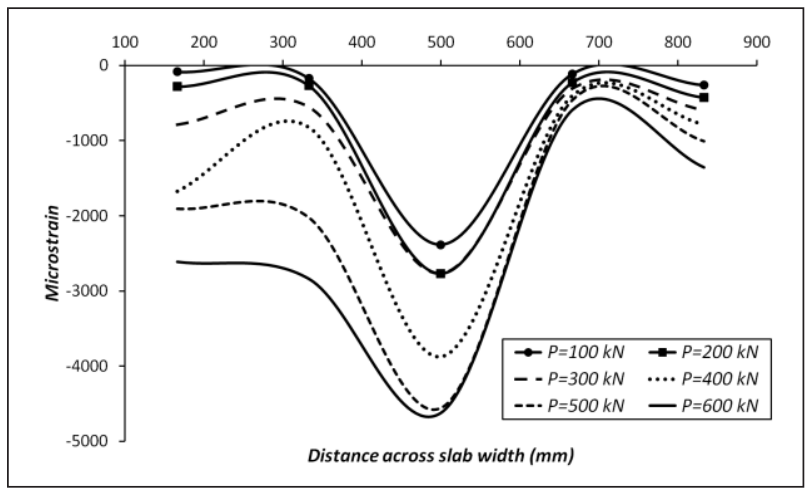

(d)

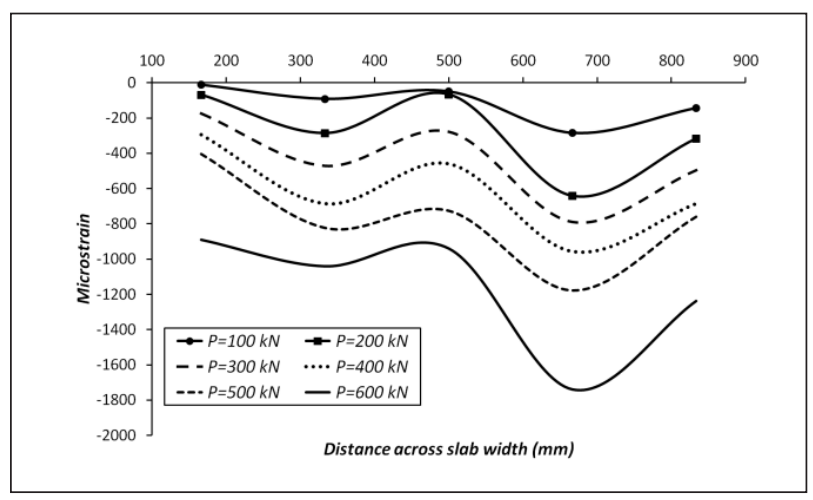

(f)

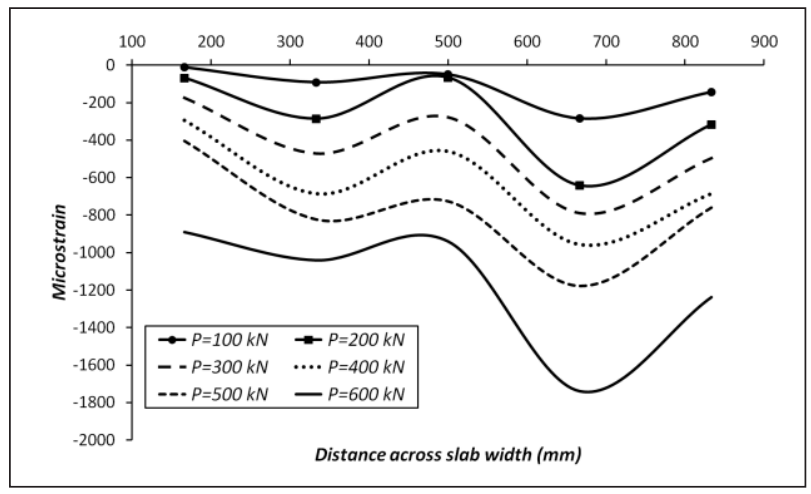

(h)

FIGURE 7. Strains across slab width near the mid-span

(a) Girder G1C20 (b) Girder G1C30 (c) Girder G2C30 (d) Girder G3C30

(e) Girder G4C20 (f) Girder G4C30 (g) Girder G5C30 (h) Girder G6C30 


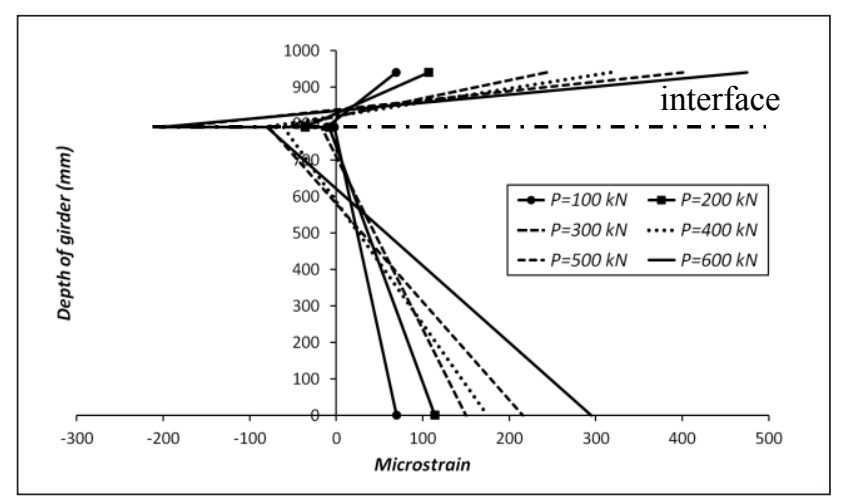

(a)

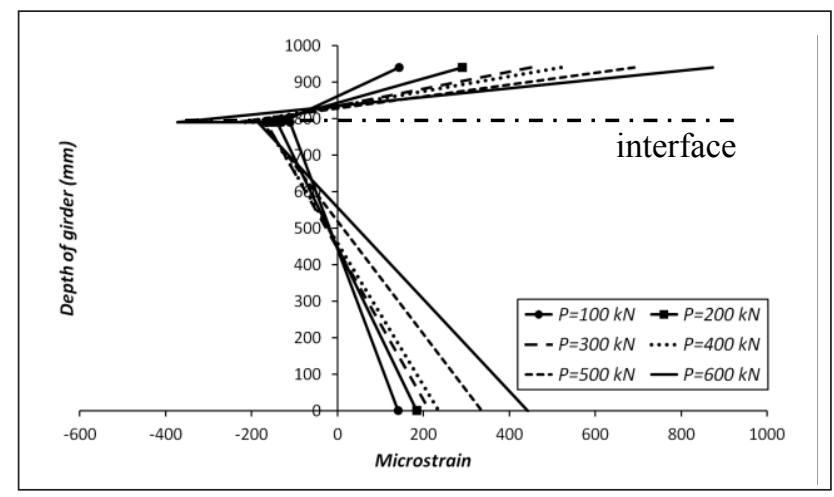

(c)

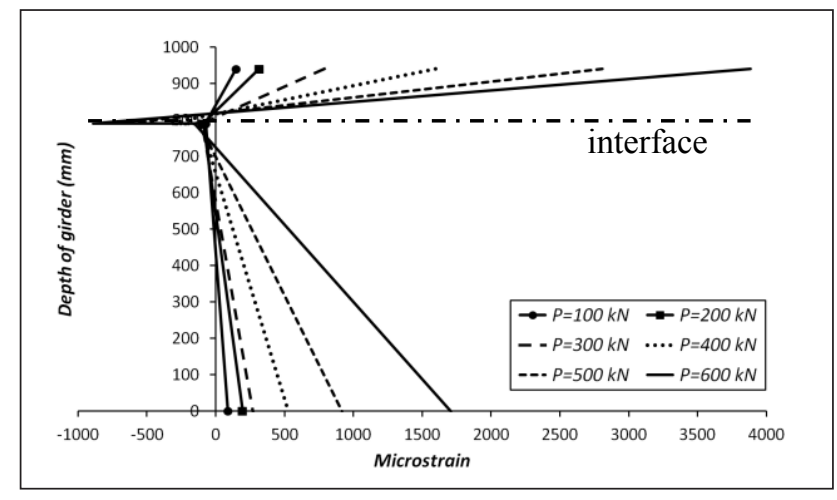

(e)

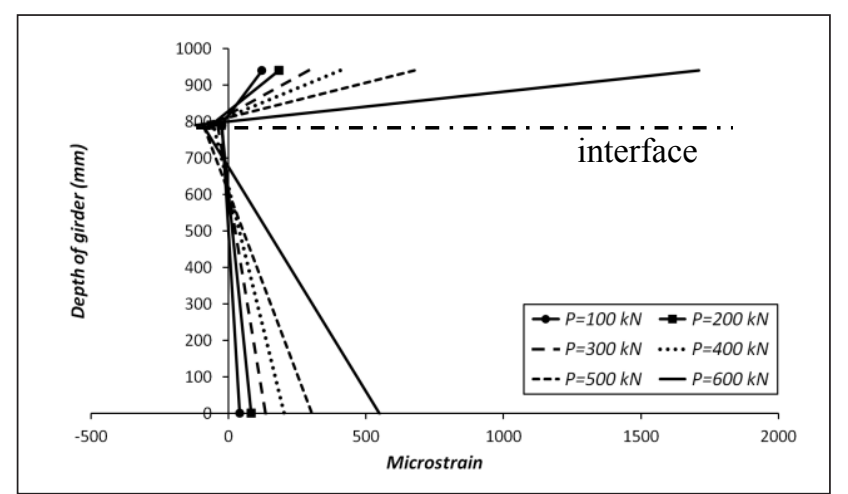

(g)

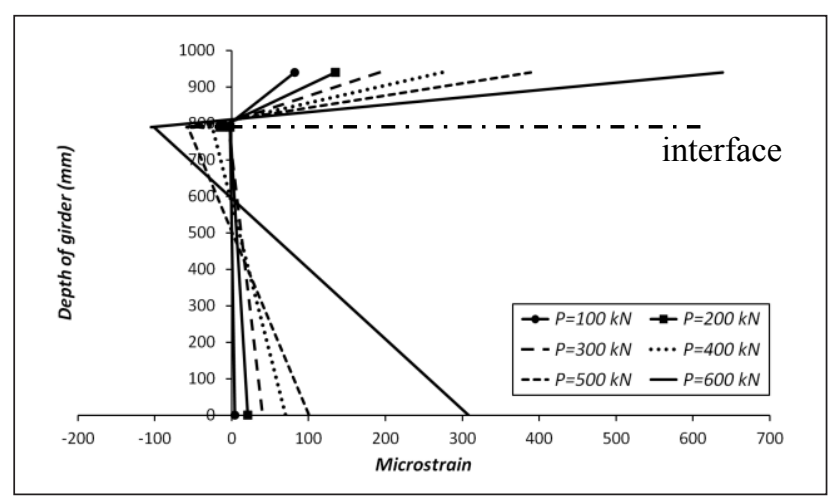

(b)

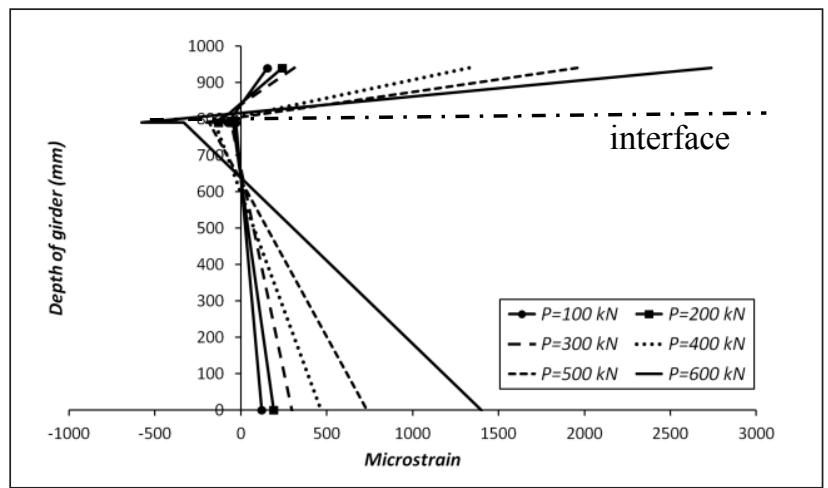

(d)

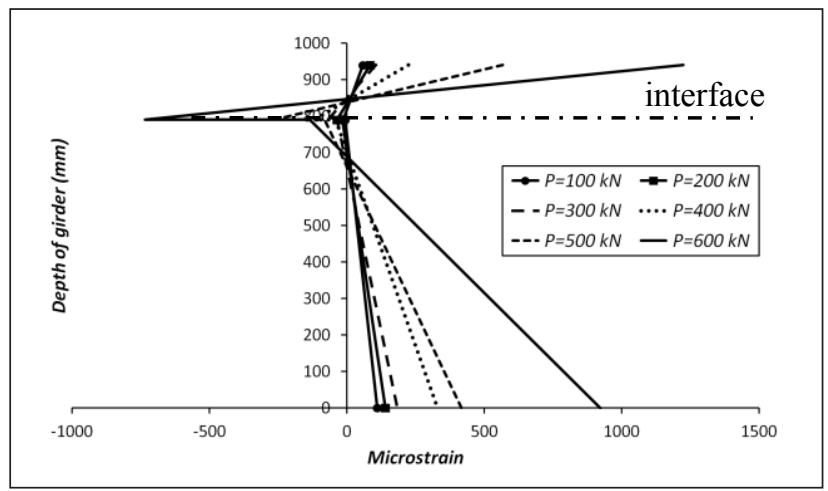

(f)

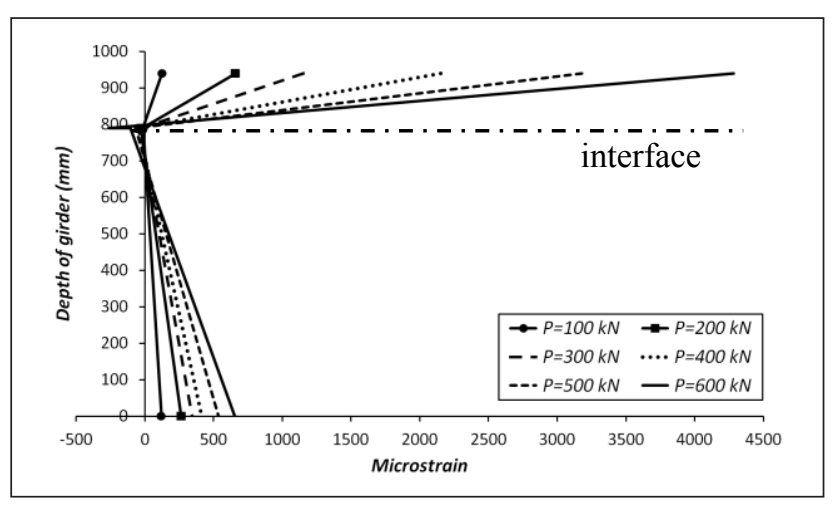

(h)

FIGURE 8. Strains across girder depth near the support

(a) Girder G1C20 (b) Girder G1C30 (c) Girder G2C30 (d) Girder G3C30

(e) Girder G4C20 (f) Girder G4C30 (g) Girder G5C30 (h) Girder G6C30 
INTERPRETATION OF THE MEASURED STRAINS ACROSS THE GIRDER DEPTH

Longitudinal strains across the depth of the girders at sections corresponding to support, quarter span and midspan are plotted in Figures 8, 9 and 10, respectively. Position of steel-concrete interface is shown in all the figures. Variations of strain are presented for six different load levels viz., 100 kN, 200 kN, 300 kN, 400 kN, 500 kN and $600 \mathrm{kN}$. These strains were measured at locations as shown in Figures 3(a) and 3(c).

Figures $8(\mathrm{a})$ to $8(\mathrm{~h})$ depict the measured strains at a section near the support corresponding to strain gauges ST21A, ST22, ST23 and ST24. It can be seen from the figures that strain at the concrete surface is tensile due to the upward reaction at the support. Tensile strains were also recorded at the lower steel flange whilst the bottom of concrete surface, $\varepsilon_{c b}$ and upper steel flange, $\varepsilon_{s t}$ experienced compressive strain. Theoretically, the existence of slip strain (i.e. $d s / d x=\varepsilon_{c b}-\varepsilon_{s t}$ ) is due to strain incompatibility

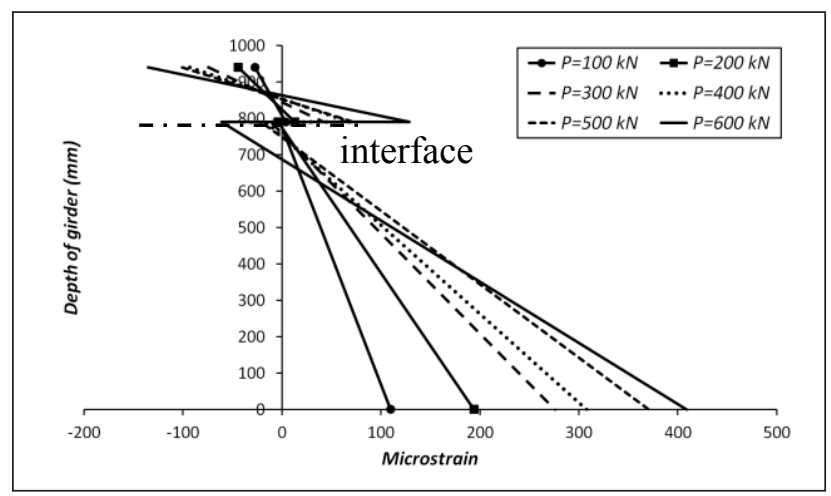

(a)

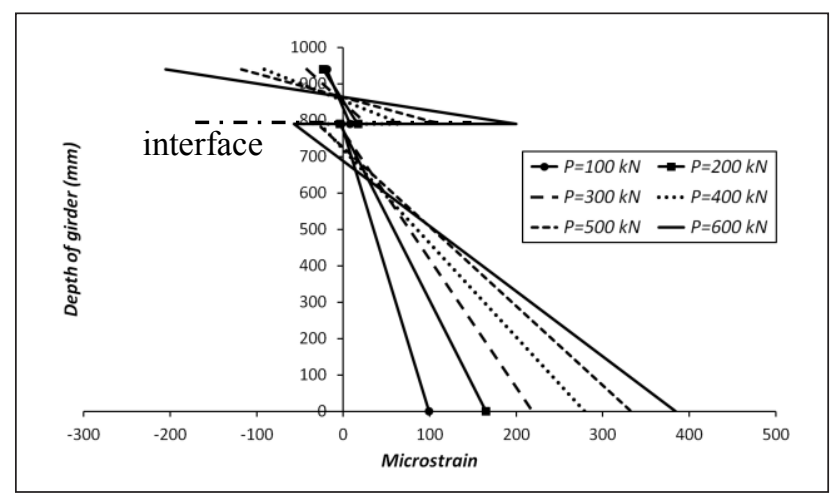

(c) at the steel-concrete interface. This incompatibility results in a step change between strains, $\varepsilon_{c b}$ and $\varepsilon_{s t}$. In the girder with low degree of interaction, the slip strain, hence the step change, is of large magnitude. At $600 \mathrm{kN}$ for instance, the values of $\varepsilon_{c b}$ and $\varepsilon_{s t}$ measured in the girder G2C30 (50\% degree of interaction) are $-373 \mu \varepsilon$ and $-185 \mu \varepsilon$, respectively, thus giving a slip strain of $-188 \mu \varepsilon$. On the other hand, the girder G4C20 which has the lowest degree of interaction (i.e. $15 \%$ ) experiences relatively higher slip strain at the same load level viz., $-736 \mu \varepsilon$. This indicates an incompatibility of strain at the interface due to the effect of partial interaction. The negative value in slip strain indicates that the bottom concrete fibre and the upper steel flange are in compression at the support as a result of upward reaction. At low load levels, however, the step change is not obvious in all cases. Also, the maximum strain of $4284 \mu \varepsilon$ at $600 \mathrm{kN}$ load level occurs at the top concrete surface of the girder G6C30 and followed by the girder G4C20 with $3885 \mu \varepsilon$. Such high magnitude of tensile strains may be attributed to the cracks at the locations where strains were measured.

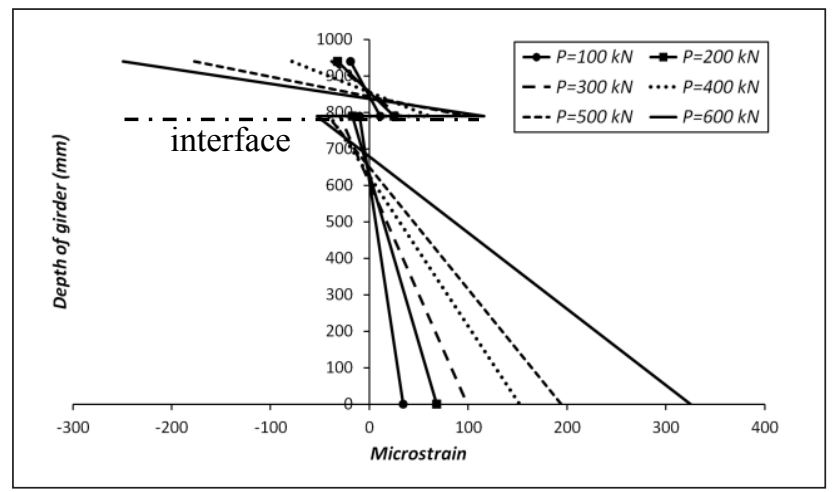

(b)

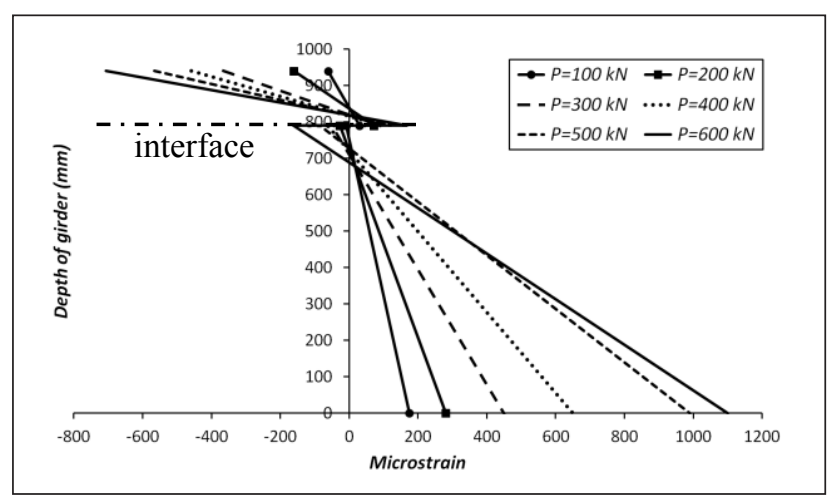

(d) 


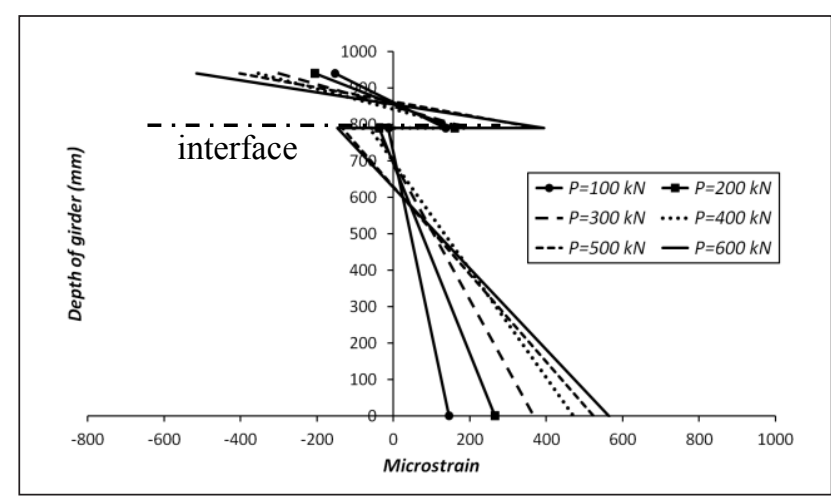

(e)

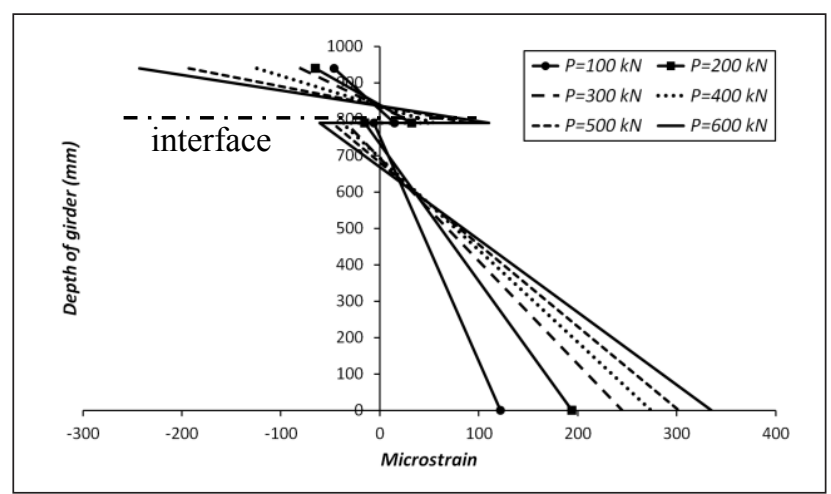

(g)

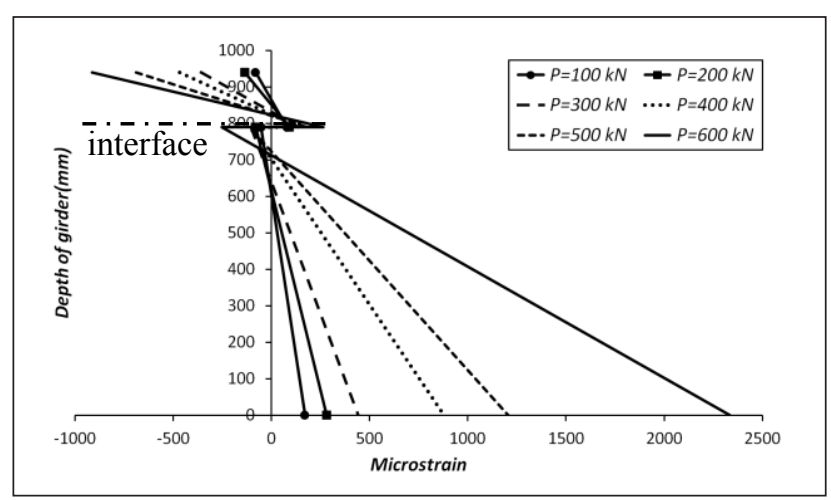

(f)

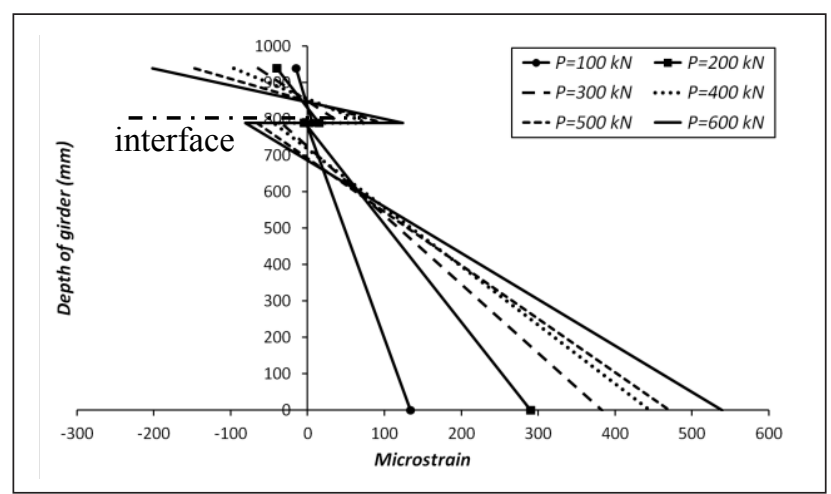

(h)

(a) Girder G1C20 (b) Girder G1C30 (c) Girder G2C30 (d) Girder G3C30

(e) Girder G4C20 (f) Girder G4C30 (g) Girder G5C30 (h) Girder G6C30

Strain measurements corresponding to the gauge locations ST13A, ST14, ST15 and ST16 at one-quarter span length are presented in Figures 9(a) to 9(h). In all girders, strains at the top concrete fibre and upper steel flange are in compression whilst tensile strains were obtained at the bottom concrete surface and lower steel flange. In this case, the step change of strains arising from strain incompatibility includes the positive and negative values. Apparently, girders with larger longitudinal spacing of studs show larger step change hence slip strain, at the steel-concrete interface. For example, girder G1C30 in Figure 9(b) with studs spacing of $135 \mathrm{~mm}$ displays strain values of $116 \mu \varepsilon$ and $-53 \mu \varepsilon$ for $\varepsilon_{c b}$ and $\varepsilon_{s t}$, respectively, thus giving the slip strain of $169 \mu \varepsilon$ at $600 \mathrm{kN}$. At the same load level, the $\varepsilon_{c b}$ of $167 \mu \varepsilon, \varepsilon_{s t}$ of $-162 \mu \varepsilon$ and thus slip strain of $329 \mu \varepsilon$ were obtained in the girder G3C30 with studs spacing of $465 \mathrm{~mm}$. The slip strain also varies between

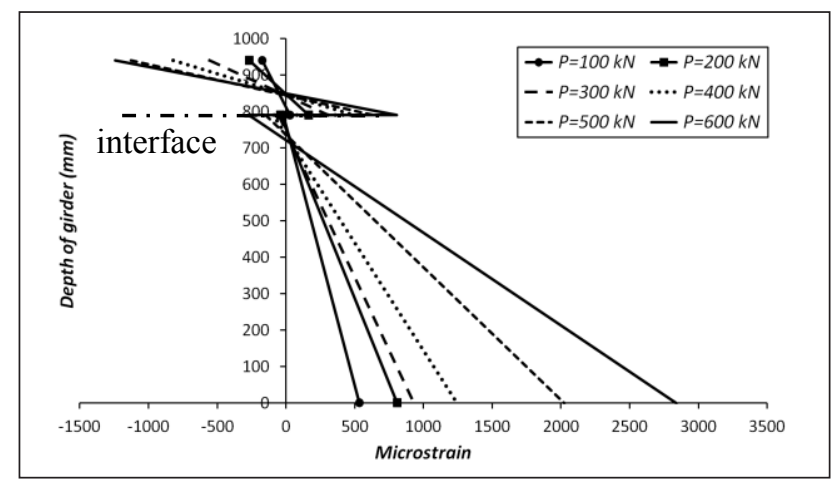

(a) girders having different diameter of studs. As shown in the figure, girder G6C30 in Figure 9(h) with $25 \mathrm{~mm}$ diameter studs appears to have relatively lower slip strain (i.e. 205 $\mu \varepsilon$ ) compared to the one with $19 \mathrm{~mm}$ studs diameter (i.e. G3C30). This is mainly due to the higher stiffness of the individual $25 \mathrm{~mm}$ studs that reduces the rate of change in slip along the interface. Results also demonstrate that use of higher strength of concrete slab results in reduced slip strain. For instance, slip strains of $190 \mu \varepsilon$ and $169 \mu \varepsilon$ were obtained for girders G1C20 and G1C30, respectively thus giving the reduction by $11 \%$. About $4 \%$ reduction in slip strain is obtained in the girder G4C30 compared to the corresponding girder G4C20. These portray the role of concrete strength towards the compatibility of strains at the interface. Variations in the slip strain or step change can be observed at lower load levels but in some cases, however, they are marginal and insignificant.

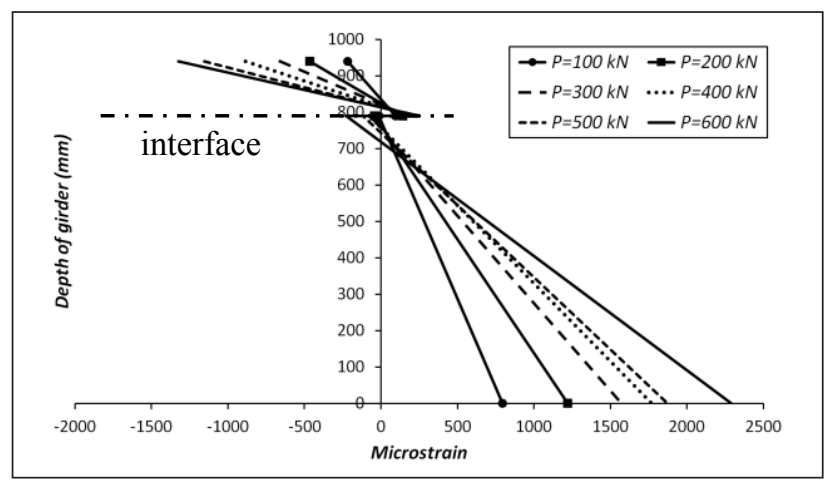

(b) 


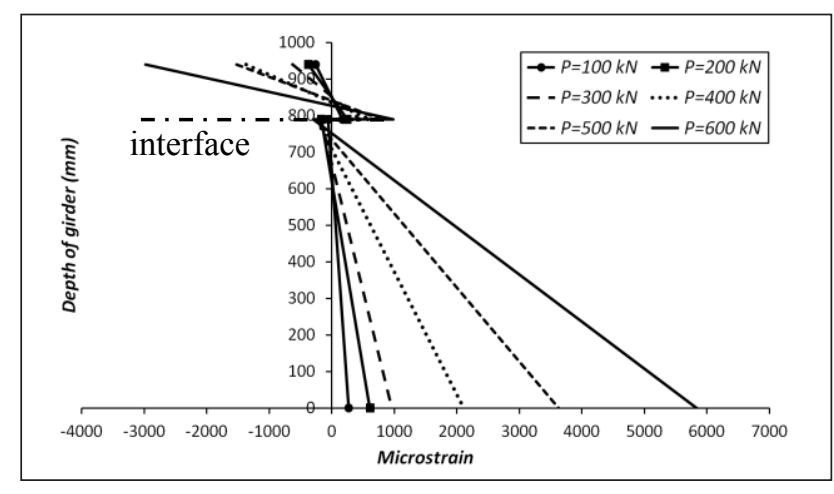

(c)

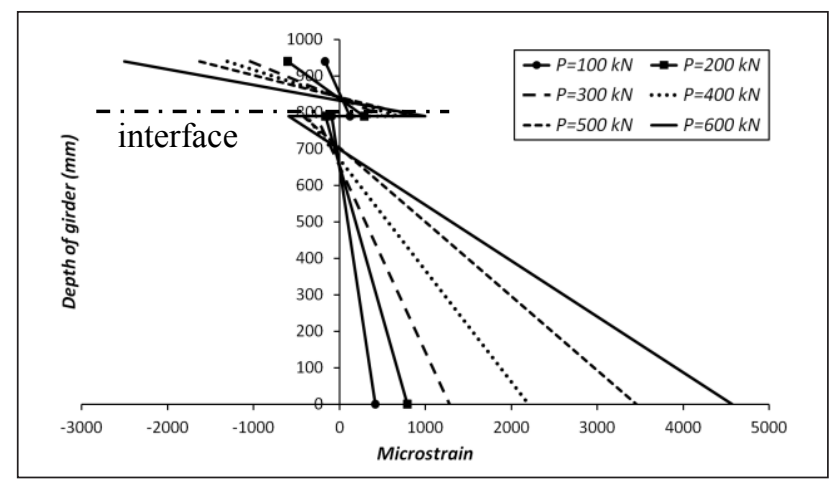

(e)

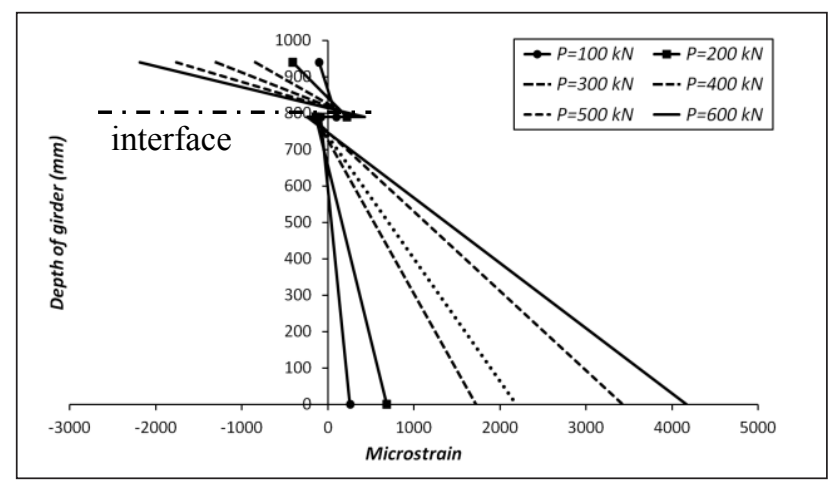

(e)

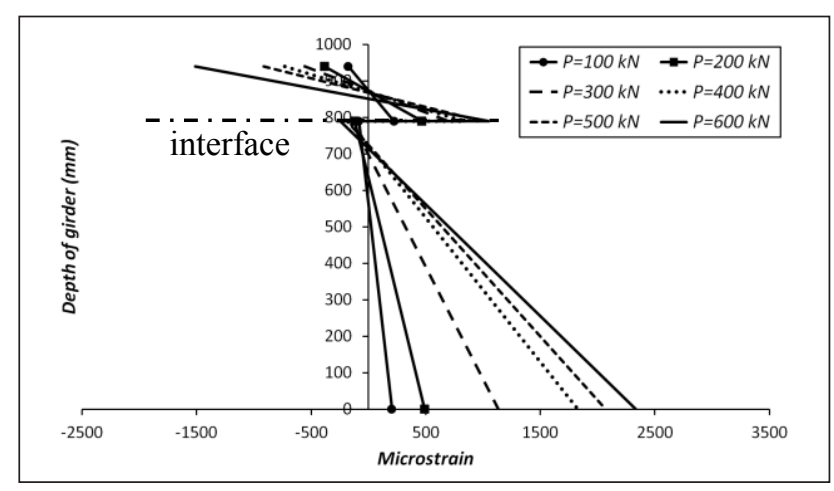

(d)

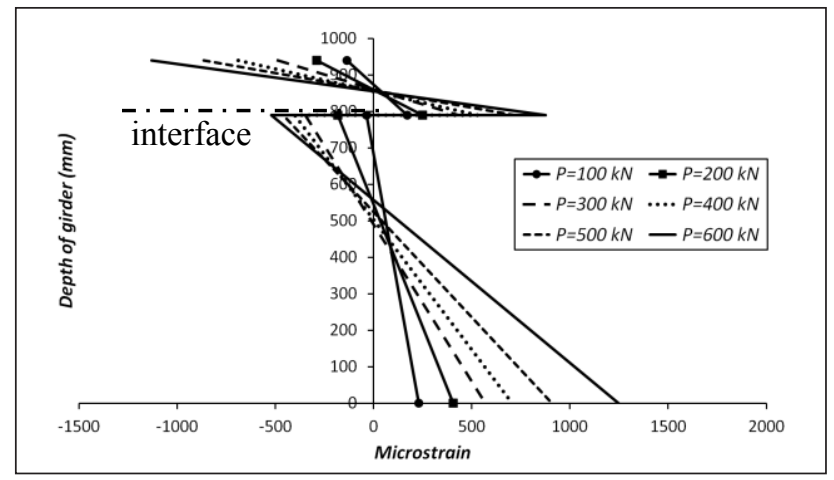

(f)

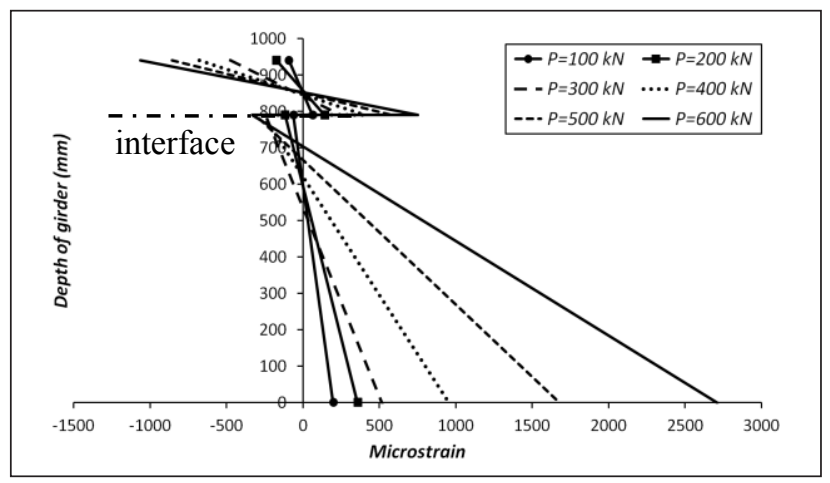

(f)

FIGURE 10. Strains across girder depth near the mid-span

(a) Girder G1C20 (b) Girder G1C30 (c) Girder G2C30 (d) Girder G3C30

(e) Girder G4C20 (f) Girder G4C30 (g) Girder G5C30 (h) Girder G6C30

Strain measurements were made across the girder depth near the mid-span at locations corresponding to gauges ST5A, ST6, ST7 and ST8. It can be observed from Figures $10(\mathrm{a})$ to $10(\mathrm{~h})$ that step change at the interface includes positive and negative strains of higher magnitude than those obtained at one-quarter span. This observation agrees with the theory by Johnson (2004) that slope of slip curve along the interface, hence the slip strain, is maximum at the mid-span. Results also demonstrate that concrete strength affects the incompatibility of strains near the midspan to some extent. In the girder G1C20 shown in Figure 10(a) for example, the slip strain obtained at $600 \mathrm{kN}$ was $1075 \mu \varepsilon$, about $125 \%$ greater than that obtained in the girder G1C30 (Figure 10(b)). It is also evident from the figures that at the same load level, use of $25 \mathrm{~mm}$ diameter stud in the girder G6C30 (Figure 10(h)) reduces the step change by
16\% compared to the girder G3C30 (Figure 10(d)) with 19 $\mathrm{mm}$ stud diameter. This can be attributed to high stiffness of the $25 \mathrm{~mm}$ diameter stud which lowers the discontinuity of strain at the interface. High compressive strains of -2981 $\mu \varepsilon$ and $-2503 \mu \varepsilon$ were recorded at top concrete surface of girders G2C30 (Figure 10(c)) and G4C20 (Figure 10(e)), respectively, indicating concrete crushing in the region where strains were measured. In addition, reduction in slip strain due to use of higher strength of concrete slab exhibit similar pattern as those measured at one-quarter span in all cases. However, effects of partial interaction on the variations of strain at top of concrete surface and at the bottom steel flange at all the sections considered could not be justified clearly due to many uncertainties such as stress distribution in the girder, deformation of the elements and experimental errors. 


\section{CONCLUSIONS}

A number of composite plate girder specimens with imperfection in the degree of shear connection were tested to failure under concentrated load applied at the mid-span. Parameters that define the degree of interaction such as longitudinal spacing of stud connectors, diameter of stud shanks, number of stud row along the steel flange and concrete grade have been considered. Strains across the slab width were measured at three selected locations viz., at sections near the support, near one-quarter span and near the mid-span. It is found that variation in strain across the slab width is uncertain, indicating that the behaviour differs from one girder to another. At support, strains are of positive magnitude due to tension in the top fibre of concrete arising from the upward reaction force. At one-quarter span, variations of tensile and compressive strains are obtained and the behaviour varies from girder to girder, indicating an arbitrary response at the top fibre of concrete. In some girders, strains at the mid-width are in compression when the shear studs were located near the section considered. Near the mid-span, however, strains at all points throughout the width of the concrete slab are in compression. Similarly, strains across the depth of the girders were measured at sections corresponding to support, one-quarter span and mid-span. Variations of step change are obtained at different load levels due to strain incompatibility at the steel-concrete interface, leading to slippage of the interacting elements along the span length which in turn, affects the performance of the composite girders. Results demonstrate that use of higher concrete strength and larger stud size could lower the level of this incompatibility indicated by the slip strain to a certain extent.

ACKNOWLEDGEMENTS

The authors acknowledge the Ministry of Education (MOE), Malaysia for the financial support under Fundamental Research Grant Scheme (FRGS/2/2014/TK02/UKM/03/1) and facilities provided by the Department of Civil and Structural Engineering, Universiti Kebangsaan Malaysia.

\section{REFERENCES}

Adekola, A. O. 1968. Partial interaction between elastically connected elements of a composite beam. International Journal of Solids and Structures 4: 1125-1135.

Allison, R. W., Johnson, R. P. \& May, I. M. 1982. Tensionfield action in composite plate girders. Proceedings of the Institution of Civil Engineers 73(2): 255-276.

Bradford, M. A. \& Gilbert, R. I. 1992. Composite beams with partial interaction under sustained loads. Journal of Structural Engineering ASCE 118(7): 1871-1883.

Daniels, J. H. \& Fisher, J. W. 1967. Static behavior of composite beams with variable load position. Fritz Engineering Laboratory Report No. 324.3, 1-52. Department of Civil Engineering, Fritz Engineering Laboratory, Lehigh University, Bethlehem, Pennsylvania.
Darehshouri, S. F., Shanmugam, N. E. \& Osman, S. A. 2011. An approximate method for shear strength of composite plate girders. Proceedings of the 7 th International Conference on Steel and Aluminium Structures (ICSAS 2011), Kuching, Sarawak, pp. 215220.

Darehshouri, S. F., Shanmugam, N. E. \& Osman, S. A. 2012. Collapse Behavior of composite plate girders loaded in shear. Journal of Structural Engineering ASCE 138(3): 318-326.

Darehshouri, S. F., Shanmugam, N. E. \& Osman, S. A. 2013. An analytical method for ultimate shear strength of composite plate girders with web openings. Engineering Structures 56: 610-620.

Jasim, N. A. 1999. Deflections of partially composite beams with linear connector density. Journal of Constructional Steel Research 49: 241-254.

Johnson, R. P. \& May, I. M. 1975. Partial interaction design of composite beams. The Structural Engineer 53(8): 305-311.

Johnson, R. P. 2004. Composite Structures of Steel and Concrete. $3^{\text {rd }}$ edition. Oxford: Blackwell Publishing Ltd.

Narayanan, R. \& Der Avanessian, N. G. V. 1983. Strength of Webs Containing Circular Cut-Outs. Proceedings of the International Association for Bridge and Structural Engineering (IABSE), P-64/83: pp. 141-152.

Newmark, N. M., Siess, C. P. \& Viest, I. M. 1951. Tests and Analysis of Composite Beams with Incomplete Interaction. Proceedings of the Society for Experimental Stress Analysis 9(1): 75-92.

Nie, J. \& Cai, C. S. 2003. Steel-concrete composite beams considering shear slip effects. Journal of Structural Engineering ASCE 129(4): 495-506.

Oehlers, D. J., Nguyen, N. T., Ahmed, M. \& Bradford, M. A. 1997. Partial interaction in composite steel and concrete beams with full shear connection. Journal of Constructional Steel Research 41(2/3): 235-248.

Oven, V. A., Burgess, I. W., Plank, R. J. \& Abdul Wali, A. A. 1997. An analytical model for the analysis of composite beams with partial interaction. Computers and Structures 62(3): 493-504.

Porter, D. M. \& Cherif, Z. E. A. 1987. Ultimate shear strength of thin webbed steel and concrete composite girders. Proceedings of the International Conference on Steel and Aluminium Structures (ICSAS 1987) 3: 55-64.

Queiroz F. D., Vellasco, P. C. G. S. \& Nethercot, D. A. 2007. Finite element modelling of composite beams with full and partial shear connection. Journal of Constructional Steel Research 63: 505-521.

Seracino, R., Oehlers, D. J. \& Yeo, M. F. 2001. Partialinteraction flexural stresses in composite steel and concrete bridge beams. Engineering Structures 23: 1186-1193.

Seracino, R., Lee, C. T., Lim, T. C. and Lim, J. Y. 2004. Partial interaction stresses in continuous composite beams under serviceability loads. Journal of Constructional Steel Research 60: 1525-1543. 
Seracino, R., Lee, C. T. and Tan, Z. 2006. Partial interaction shear flow forces in continuous composite steelconcrete beams. Journal of Structural Engineering ASCE 132(2): 227-236.

Shanmugam, N. E. \& Baskar, K. 2003. Steel-concrete composite plate girders subject to shear loading. Journal of Structural Engineering ASCE 129(9): 1230-1242.

Shanmugam, N. E. \& Baskar, K. 2006. Design of composite plate girders under shear loading. steel and composite structures. An International Journal 6(1): 1-14.

Shanmugam, N. E. \& Baskar, K. 2008. Ultimate load behaviour of webs in steel-concrete composite plate girders. The IES Journal Part A: Civil \& Structural Engineering 1(2): 123-140.

Shanmugam, N. E., Basher, M. A. \& Khalim, A. R. 2009. Ultimate load behavior of horizontally curved composite plate girders. steel and composite structures. An International Journal 9(4): 325-348.

Sherafati, A., Farimani, R. \& Azizinamini, A. 2013. Effect of concrete slab on shear capacity of composite plate girders under positive moment. Journal of Bridge Engineering ASCE 18(2): 89-98.

Wang, A. J. \& Chung, K. F. 2008. advanced finite element modelling of perforated composite beams with flexible shear connectors. Engineering Structures 30: 27242738.
Yatim, M. Y. M., Shanmugam, N. E. \& Wan Badaruzzaman, W. H. 2012. Ultimate Strength of Partially Connected Composite Plate Girders with Web Openings. Proceedings of the 10th International Conference on Advances in Steel Concrete Composite and Hybrid Structures (ASCCS 2012), pp. 686-693.

Yatim, M. Y. M., Shanmugam, N. E. \& Wan Badaruzzaman, W. H. 2015. Tests of partially connected composite plate girders. Thin-Walled Structures 91: 13-28.

Mohd Yazmil Md Yatim*

Nandivaram E. Shanmugam

Structures, Materials and Construction Management Research Group

Department of Civil and Structural Engineering

Faculty of Engineering and Built Environment

Universiti Kebangsaan Malaysia

43600 UKM Bangi, Selangor

Malaysia

Tel: +603 89216202

*Corresponding author; E-mail: mymy@ukm.edu.my

Received Date: $15^{\text {th }}$ April 2015

Accepted Date: $13^{\text {th }}$ Oct 2015 